\title{
Nos fratres conventus sancti Adalberti. Dokumenty wystawione przez konwent dominikanów wrocławskich w latach 1390-1424
}

Zarys treści: W Archiwum Państwowym we Wrocławiu zachowało się 10 dokumentów z lat 1390-1424, których wystawcą jest dominikański konwent św. Wojciecha we Wrocławiu. Grupa ta jest wyjątkowa na tle całej polskiej prowincji Zakonu Kaznodziejów. Przedmiotem artykułu jest edycja wspomnianych dokumentów oraz omówienie ich wartości źródłowej do dziejów dominikanów wrocławskich na przełomie XIV i XV stulecia.

\begin{abstract}
There are ten documents from 1390-1424 preserved in the State Archives in Wrocław, issued by the Dominican convent of St. Adalbert in Wrocław. This group is unique for the entire Polish province of the Dominican Order. The subject of the article is the edition of the abovementioned documents and a presentation of their source value for the history of Wrocław's Dominicans at the turn of the fifteenth century.
\end{abstract}

Słowa kluczowe: dominikanie, dokumenty, konwent, Wrocław

Keywords: Dominicans, documents, convent, Wrocław

Przełom XIV i XV stulecia stanowi szczególnie interesujący okres w dziejach polskich dominikanów. Wyznaczają go ramowo daty 1392-1393, czyli bunt prowincjała Piotra Wasserrabe przeciwko generałowi Rajmundowi z Kapui ${ }^{1}$ oraz 1415-1417, gdy polska prowincja Zakonu Kaznodziejów została podzielona, a klasztory należące do kontrat leżących poza granicami Królestwa Polskiego weszły do nowo utworzonej prowincji Dolnych Niemiec (Theutonia Inferior) $)^{2}$. W tym czasie, w literaturze określanym mianem okresu „walk wewnętrznych i prób oderwania Śląska od prowincji” oraz wzrostu znaczenia klasztoru wrocławskiego i rywalizacji o pierwszeństwo z Krakowem ${ }^{3}$, bracia od św. Wojciecha odgrywali niepoślednią rolę $\mathrm{w}$ prowincji, znajdując się w centrum burzliwych wówczas wydarzeń. I chociaż historycy zajmowali się różnymi aspektami dziejów konwentu wrocławskiego, to aktualna pozostaje ocena

1 R.-J. Loenertz, Une ancienne chronique des provinciaux dominicains de Pologne, „Archivum Fratrum Praedicatorum”, 21, 1951, s. 35-36; J. Kłoczowski, Dominikanie polscy na Ślasku w XIII-XIV wieku, Lublin 1956, s. 193-198; P. Kielar, Studia nad kultura szkolna i intelektualna dominikanów prowincji polskiej w średniowieczu, w: Studia nad historia dominikanów $w$ Polsce 1222-1972, t. 1, red. J. Kłoczowski, Warszawa 1975, s. 360-363; A. Zajchowska, Franciszek Oczko i poczatki reformy obserwanckiej w polskiej prowincji dominikanów, „Średniowiecze Polskie i Powszechne”, 4, 2012, s. $208-216$.

2 J. Fijałek, Dwaj dominikanie krakowscy Jan Biskupiec i Jan Falkenberg. W pięćsetna rocznicę odwołania satyry antypolskiej Falkenberga w Rzymie w 1424 roku, w: Księga pamiątkowa ku czci Oswalda Balzera, t. 1, Lwów 1925, s. 287-296; J. Turek, Podziat polskiej prowincji dominikanów w czasach prowincjalatu Jana Biskupca w latach 1415-1417, Przegl. Hist., 106, 2015, nr 2, s. 287-324.

3 J. Kłoczowski, Dominikanie polscy na Ślasku, s. 191-202; P. Kielar, Studia nad kultura, s. 460-464. 
wyrażona przez Krzysztofa Kaczmarka, że „stan badań wydaje się niewspółmiernie słabo zaawansowany w stosunku do potencjalnych możliwości tkwiących w przebogatej podstawie źródłowej”‘. Piszący o wrocławskich dominikanach z przełomu XIV i XV w. rzadko wykorzystywali dokumenty wystawione przez konwent, choć z tego właśnie okresu pochodzi wyjątkowa grupa takich źródeł. Niektóre z nich nie były dotąd znane w literaturze, inne zaś wykorzystywane tylko powierzchownie, nierzadko jedynie na podstawie regestów. $\mathrm{Z}$ tego względu warto opublikować wspomniane dokumenty i przyjrzeć się informacjom, jakie przynoszą na temat wrocławskich dominikanów w tak istotnym dla ich dziejów okresie.

Ufundowany w $1226 \mathrm{r}$. wrocławski klasztor dominikanów był w średniowieczu jednym z najważniejszych konwentów w całej prowincji, głównym domem kontraty śląskiej i ważnym ośrodkiem szkolnictwa zakonnego. Funkcjonował nieprzerwanie przez blisko sześć stuleci, aż do kasaty w $1810 \mathrm{r}$. Obecnie dokumenty ze zlikwidowanego konwentu przechowywane są w Archiwum Państwowym we Wrocławiu, w zespole o sygnaturze Rep. 57, przy czym dla powojennych badaczy stały się dostępne dopiero po 1980 r., po rewindykacji zasobów archiwalnych z byłej NRD ${ }^{5}$. W zespole tym zachowały się do naszych czasów 302 średniowieczne dyplomy. Niestety pergaminy XIV-wieczne uległy zniszczeniu w czasie ostatniej wojny. W dawnych sygnaturach jest duża wyrwa pomiędzy numerami 51 a 101 (okres 1302-1404) ${ }^{6}$. Najliczniejszą grupę stanowią dokumenty XV-wieczne. Dotyczą one przede wszystkim spraw majątkowych, różnego rodzaju transakcji, sporów i nadań, są tu również testamenty mieszczan wrocławskich i listy generałów zakonu. W tej masie znajduje się siedem dokumentów, których wystawcami byli bracia z wrocławskiego klasztoru. Dwa z nich pochodzą z interesującego nas okresu (aneks, nr 4 i 7). Wojennej zawieruchy nie przetrwał jeszcze jeden, często przywoływany w literaturze dyplom z 3 VI 1404 (dawniej nr 100). Szczęśliwie regest w inwentarzu z 1819 r. przynosi sporo informacji na temat jego wystawcy i treści (aneks, nr 3)7. Przynajmniej częściowo można je pozytywnie zweryfikować na podstawie dokumentu z 29 XII 1424 (nr 10)

Z natury rzeczy dokumentów wystawionych przez konwent należy szukać w archiwach odbiorców. Sporej liczby dyplomów dostarcza archiwum dawnego klasztoru dominikanek wrocławskich, przechowywane obecnie w zespole Rep. $58^{9}$. Zespół ten, liczący 644 dokumenty wystawione do końca XV w., zachował się niemal w komplecie i jest cennym źródłem do średniowiecznych dziejów nie tylko dominikanek, ale także braci z nieodległego klasztoru św. Wojciecha. Znajduje się w nim sześć dokumentów $\mathrm{z}$ lat 1390-1415, wystawionych przez wrocławskich predykantów (nr 1, 2, 5, 6, 8, 9).

Z ogromnych zasobów AP we Wrocławiu przejrzałem repozytury 57 i $58^{10}$. Posiłkowałem się wspomnianym już inwentarzem z 1819 r., a we współczesnym katalogu sprawdziłem wszystkie dokumenty

\footnotetext{
${ }^{4}$ K. Kaczmarek, Konwent dominikanów wrocławskich w późnym średniowieczu, Wrocław 2008, s. 14.

${ }^{5}$ R. Stelmach, Źródła do dziejów śląskich dominikanów zachowane w archiwach wrocławskich, w: Dominikanie. GdańskPolska - Europa, red. D.A. Dekański, A. Gołembnik, M. Grubka, Gdańsk 2003, s. 520, 527-528.

${ }^{6}$ Por. inwentarz z 1819 r.: AP Wrocław, Rep. 135, t. 50. Zaginione dokumenty dotyczyły głównie nadań i przywilejów papieskich, biskupich i książęcych. O niektórych posiadamy pewne informacje z prac autorów piszących w XIX i na początku XX w.

7 AP Wrocław, Rep. 135, t. 50, s. 529-530, nr 100. Ze względu na częste wykorzystywanie w literaturze został on również poniżej opublikowany. Na tym regeście opierali się np. J. Kłoczowski, Dominikanie polscy na Śląsku, s. 196; K. Kaczmarek, Konwent dominikanów wrocławskich, s. 22; tenże, Szkoty i studia polskich dominikanów w okresie średniowiecza, Poznań 2005, s. 143, 470, 539; A. Zajchowska, Franciszek Oczko, s. 205. Należy dodać, że ów regest jest wyjątkowo bogaty w szczegóły. Inne są zwykle znacznie uboższe, w szczególności nie podają imion braci. O tym, jak niepełne mogą być niektóre regesty może świadczyć fakt, że w regeście dokumentu z 1407 r. (nr 6) występuje zaledwie trzech braci, podczas gdy dokument wymienia ich 16

${ }^{8}$ Dokument ten również został poniżej wydany, choć wybiega nieco poza ramy czasowe przedstawione na wstępie, umożliwi to bowiem czytelnikowi samodzielne porównanie zawartych w nim informacji. Pozostałe dokumenty (z lat 1436-1470) wystawione przez konwent wrocławski to: Rep. 57, nr 115 (165a), 129 (177), 217 (255) i 221 (263). Wojny nie przetrwał natomiast dokument z $1356 \mathrm{r}$. ( $\mathrm{nr} 75)$.

9 R. Stelmach, Źródła do dziejów ślaskich dominikanów, s. 528-529; tenże, Dokumenty do dziejów żeńskich klasztorów na Ślasku zachowane w Archiwum Państwowym we Wrocławiu, w: Sanctimoniales. Zakony żeńskie w Polsce i Europie Środkowej (do przełomu XVIII i XIX wieku), red. A. Radzimiński, D. Karczewski, Z. Zyglewski, Toruń 2010, s. 427-429, 435-437.

${ }^{10} \mathrm{~W}$ zespole Rep. 57 znalazły się także akta brzeskiego konwentu dominikanów. Z racji niedużej odległości od Wrocławia obydwa konwenty utrzymywały regularne kontakty, dlatego wśród dokumentów braci brzeskich można było spodziewać się również dyplomów konwentu wrocławskiego.
} 
pergaminowe $\mathrm{z}$ lat $1390-1424^{11}$. Kwerendą objąłem także dokumenty $\mathrm{w}$ oprawach wybranych podominikańskich kodeksów przechowywanych w Bibliotece Uniwersyteckiej we Wrocławiu oraz zasoby Archiwum Polskiej Prowincji Dominikanów w Krakowie ${ }^{12}$. Tylko w podominikańskich zespołach AP we Wrocławiu odnalazłem interesujące mnie dokumenty. Można mieć nadzieję, że dalsze kwerendy dostarczą kolejnych nieznanych źródeł.

Intensywnie rozwijające się w ostatnim czasie badania nad składami osobowymi poszczególnych klasztorów, kadrą nauczającą i studentami szkół dominikańskich oraz inkwizycją wykorzystują przede wszystkim źródła normatywne, akta kapituł generalnych i prowincjalnych, epistolarne, memoratywne, księgi zmarłych, zbiór formuł listów prowincjałów (tzw. Dictamina litterarum), księgi z dawnej biblioteki klasztornej czy wreszcie wiadomości rozproszone w dokumentach, zwykle innej niż zakonna proweniencji ${ }^{13}$.

Wydanych poniżej 10 dokumentów z lat 1390-1424 łączy jeden wystawca - dominikański konwent św. Wojciecha we Wrocławiu. Zasadne będzie przedstawienie kilku obserwacji wynikających z lektury publikowanych dokumentów, tym bardziej że dyplomatyka zakonna i zwyczaje kancelaryjne nie wzbudzały, jak dotąd, zainteresowania badaczy dziejów polskich dominikanów. Mam jednak świadomość, że poniższe uwagi będą miały charakter przyczynkowy. Nie można bowiem wyciągać zbyt daleko idących wniosków na podstawie zaledwie 10 dokumentów. Do bardziej precyzyjnych badań konieczny będzie szerszy materiał, dotyczący dłuższego zakresu chronologicznego.

W literaturze funkcjonuje opinia, że w intytulacji dokumentów wymieniano ,tylko kilku zakonników tworzących ścisłą elitę władzy"14. Rzeczywiście tak się zdarzało (zob. nr 10), nie było to jednak regułą. W intytulacji dokumentu z $1415 \mathrm{r}$. (nr 9) wymieniono aż 26 imion. W pozostałych dokumentach (nr 1-8) analogiczne listy są tylko nieco krótsze. Dla porównania dysponujemy kilkoma dokumentami wystawionymi w tym samym czasie przez inne konwenty. Potwierdzają one praktykę wymieniania $\mathrm{z}$ imienia kilkunastu braci. Wystawcami dokumentu konwentu głogowskiego z 10 X 1401 było 12 braci $^{15}$, w Cieszynie z 14 II 1408 - 17 $7^{16}$, na dyplomie elbląskich dominikanów z 13 I 1409 - 18 zakonników ${ }^{17}$. Konwent tczewski w dokumencie z 4 IV 1413 reprezentowało aż 21 braci $^{18}$, natomiast na dokumencie konwentu poznańskiego z 11 października tego samego roku występowało 11 braci $^{19}$. Nieco skromniej

${ }^{11}$ Katalog średniowiecznych dokumentów przechowywanych w Archiwum Państwowym we Wroclawiu, oprac. R. Stelmach, Racibórz 2014; por. Katalog dokumentów przechowywanych w archiwach państwowych Dolnego Ślaska, t. 6: 1380-1391, oprac. M. Chmielewska, Wrocław 1995; tamże, t. 7: 1392-1400, oprac. R. Stelmach, Wrocław 1993.

${ }_{12}$ W Archiwum Polskiej Prowincji Dominikanów w Krakowie znajduje się dokument (perg. 122) wystawiony przez konwent krakowski w 1440 r. W tym samym archiwum znajdują się nowożytne kopiarze dokumentów poszczególnych klasztorów, ale są w nich głównie dokumenty zewnętrznych wystawców.

13 R. Kubicki, Środowisko dominikanów kontraty pruskiej od XIII do połowy XVI wieku, Gdańsk 2007, zwł. s. 151-193; K. Kaczmarek, Konwent dominikanów wrocławskich; tenże, Szkoły i studia, s. 393-557; M. Zdanek, Szkoty i studia dominikanów krakowskich w średniowieczu, Kraków 2005, s. 166-184; tenże, Regensi dominikańskiego studium generalnego w Krakowie do 1596, „Przegląd Tomistyczny”, 16, 2010, s. 77-124; P. Kras, Dominican Inquisitors in Medieval Poland $\left(14^{\text {th }}-15^{\text {th }}\right.$ c.), w: Praedicatores inquisitores, t. 1: The Dominicans and the Medieval Inquisition, red. W. Hoyer, Roma 2004, s. 249-309, zwł. s. 295-309; M. Zdanek, Inkwizytorzy dominikańscy w diecezji krakowskiej w średniowieczu, w: Inkwizycja papieska w Europie Środkowo-Wschodniej, red. P. Kras, Kraków 2010, s. 219-237. Tam dalsza literatura i wykazy źródeł.

${ }_{14}$ K. Kaczmarek, Konwent dominikanów wrocławskich, s. 22.

${ }^{15}$ AP Wrocław, Rep. 77, nr 3 (5): „nos fratres conventus Glogoviensis [...] videlicet frater Johannes de Lewyn prior, frater Petrus Blumil subprior, frater Nicolaus Schonaw, frater Mathias Parchwis, frater Stephanus Rineri, frater Johannes Sculteti, frater Jacobus Brigensis, frater Johannes Lobyn, frater Nicolaus Molendinatoris, frater Nicolaus Leyscenberg, frater Johannes Lenbis, frater Nicolaus Braxatoris ceterique fratres".

${ }^{16}$ Regesty dokumentów przechowywanych na Górnym Ślasku, t. 2, oprac. A. Barciak, K. Müller, Opava-Opole-Katowice 2011, s. 41, nr 70.

${ }^{17}$ AP Gdańsk, sygn. 368/II,26 [IV,81]; R. Kubicki, Środowisko dominikanów, s. 53, zob. tamże spis alfabetyczny zakonników, rozdz. 5.1.

18 S. Kujot, Rok 1410. Wojna, „Rocznik Towarzystwa Naukowego w Toruniu”, 17, 1910, s. 376-378, nr 2; interesujące jest, że identycznie brzmiąca lista imion występuje na analogicznym dokumencie konwentu tczewskiego z 1416 r.: Geheimes Staatsarchiv Preussischer Kulturbesitz, XX. HA, Pergament-Urkunden, Schieblade 51, nr 26; R. Kubicki, Środowisko dominikanów, s. 53 i rozdz. 5.1.

${ }^{19}$ KDWlkp., t. 7, Warszawa-Poznań 1985, nr 717. 
na tym tle prezentuje się dokument mniejszego od tamtych konwentu lubelskiego z 11 IV 1409. Przywołano $\mathrm{w}$ nim tylko 6 imion $^{20}$. Z całą pewnością w intytulacji nie wymieniano wszystkich członków wspólnoty. Formułę zawsze kończą słowa ceterique fratres. Jeśli przyjąć, że we wrocławskim klasztorze żyło wówczas, podobnie jak sto lat później, ok. 60-80 braci ${ }^{21}$, nasuwa się pytanie, kim byli bracia wymienieni z imienia? Czy decydowała wyłącznie obecność na kapitule w danym dniu, czy kierowano się jakimiś innymi względami?

Z pomocą przychodzą zarządzenia kapituł generalnych Zakonu Kaznodziejów. Paryska kapituła z 1248 r. postanawiała, by dokumenty opieczętowywane były za wiedzą całej wspólnoty, a przynajmniej jej większości („nisi cum consensu conventus vel maioris partis”) ${ }^{22}$. Kapituły z 1276 i 1288 r. dodawały zasadę, że pieczęć konwentu może być używana wyłącznie w obecności wszystkich braci, którym należało najpierw odczytać treść dokumentu na kapitule konwentualnej (,in capitulo coram fratribus [...] in conspectu omnium" ${ }^{23}$. Dokument wystawiany w imieniu konwentu był więc najpierw odczytywany na kapitule konwentualnej, a następnie - za zgodą przynajmniej większości braci - pieczętowany. Że taka procedura zachowywana była w przypadku wystawiania i pieczętowania omawianych tu dyplomów jednoznacznie świadczy narracja dokumentu z 1395 r. (nr 2). Bracia zgromadzeni na kapitule wystawili dokument zgodnie z wolą starszych wspólnoty i z przyzwoleniem prowincjała (,licencia [...] provincialis [...] ac aliorum dicti monasterii seniorum assensu et voluntate”). Powstaje pytanie, kto należał do owej decydującej większości?

Odpowiedzi na to pytanie można poszukać, przyglądając się innym czynnościom, których konwent miał dokonywać na kapitule. Najstarsze konstytucje Zakonu Kaznodziejów stanowiły, że do wyboru przeora mogą przystąpić tylko ci członkowie wspólnoty, którzy żyli w niej przynajmniej rok od złożenia profesji ${ }^{24}$. W niedługim czasie skład elektorów ograniczono do braci żyjących w danym konwencie przynajmniej 4 lata, a próbowano tę granice przesuną́ nawet na 10 lat ${ }^{25}$. Kapituły nie musiały być jednak zgromadzeniami wyborczymi. Miały one także wpływ na podejmowanie decyzji w imieniu całej wspólnoty. Dla przykładu kapituła konwentu gdańskiego z 1446 r. zatwierdziła umowę z wielkim mistrzem krzyżackim ${ }^{26}$.

Jak widać, zakonne przepisy nakazywały ważne z punktu widzenia wspólnoty decyzje podejmować kolegialnie, ale o najważniejszych sprawach, jak wybór przeora, mogli decydować tylko najstarsi i najbardziej doświadczeni członkowie kapituły. Rady discretorum fratrum przeor miał słuchać również w innych sprawach, np. przy wyborze subprzeora ${ }^{27}$, natomiast kapituła generalna z $1265 \mathrm{r}$. zakazywała braciom głosić kazania „sine licencia prioris sui in capitulo de consilio discretorum [fratrum] sibi data" ${ }^{28}$. Kapituła generalna odprawiona w 1403 r. w Erfurcie podkreślała zaś, że żaden brat nie może opuścić klasztoru bez zgody przełożonych „et maioris partis fratrum discretorum tunc presencium in conventu”29. Owi „fratres, qui bonae sint discretionis” według XIII-wiecznego generała zakonu Humberta z Romans byli doradcami (tzw. consiliarii) przeora przy wyborze klasztornych urzędników

20 ZDMłp., t. 5, Wrocław 1970, nr 1225.

${ }^{21}$ K. Kaczmarek, Konwent dominikanów wrocławskich, s. 26-31, 205-226, 232-241.

${ }^{22}$ Acta capitulorum generalium Ordinis Praedicatorum [dalej: ACGOP], t. 1, wyd. B.M. Reichert, w: Monumenta Ordinis Praedicatorum Historica, t. 3, Romae 1898, s. 42; por. też tamże, s. 52-53, 58.

${ }^{23}$ Tamże, s. 187, 245; zob. G.R. Galbraith, The Constitution of the Dominican Order 1216-1360, Manchester 1925, s. $116-117$.

${ }^{24}$ De oudste Constituties van de Dominicanen. Voorgeschiedenis, Tekst, Bronnen Ontstaan en Ontwikkeling (1215-1237), wyd. A.H. Thomas, Leuven 1965, s. 359.

${ }_{25}$ ACGOP, t. 1, s. 7, 85, 90, 94, 146, 151, 156; tamże, t. 2, s. 313, 321 (kapituły z lat 1347 i 1348 próbowały wprowadzić wymóg 10 lat, ale uchwała ta nie doczekała się zatwierdzenia przez trzecią kapitułe); G.R. Galbraith, The Constitution, s. 111-116; W.A. Hinnebusch, The History of the Dominican Order, t. 1, New York 1965, s. 217-218.

${ }^{26}$ Geheimes Staatsarchiv Preussischer Kulturbesitz, XX. HA, Pergament-Urkunden, Schieblade 54, nr 23a; R. Kubicki, Środowisko dominikanów, s. 36, 61.

27 De oudste Constituties, s. 359.

${ }^{28}$ ACGOP, t. 1, s. 128.

${ }^{29}$ ACGOP, t. 3, s. 74. 
i zarządzaniu majątkiem wspólnoty. W przypadku konieczności przywieszenia do dokumentu pieczęci konwentu powinni jednak najpierw przedstawić sprawę całej kapitule ${ }^{30}$.

Można przypuszczać, że po omówieniu sprawy na kapitule to właśnie discreti fratres byli wymieniani w intytulacji dokumentów. W przypadku wspomnianych wyżej dokumentów innych konwentów można dostrzec, że zakonnicy funkcyjni, chociaż zawsze wymienieni w intytulacji w pierwszej kolejności, stanowili mniejszość - od 16,7 do 47\%, przy czym tylko w jednym przypadku liczba braci sprawujących urzędy i pozostałych zbliżyła się do połowy, a w innych zdecydowaną większość stanowiła ta druga grupa. Relatywnie nieduży odsetek wynika oczywiście przede wszystkim z faktu, że urzędy pełniło niewielu braci w porównaniu z ogólną liczbą zakonników zamieszkujących dany klasztor. W przypadku konwentu wrocławskiego odsetek braci funkcyjnych był jednak znacznie wyższy. Wynosił od 42,3 do nawet $80 \%$. W przypadku połowy dokumentów udział niefunkcyjnych braci oscyluje wokół 40-50\% ${ }^{31}$. Różnica w porównaniu z innymi konwentami może wynikać z różnych powodów, np. z tego, że klasztor wrocławski był większy od wcześniej wymienionych, mieściły się w nim wszystkie rodzaje szkół partykularnych ze swoją kadrą nauczycieli, rezydowali tu inkwizytorzy. Słowem przebywało tu więcej braci funkcyjnych. Widać jednak, że przy wystawianiu dokumentu obecni byli nie tylko członkowie owej klasztornej elity władzy i nauczania, ale prawdopodobnie wszyscy spośród discretorum fratrum, którzy mogli stawić się na kapitule. Poznanie biografii braci wymienionych w intytulacjach wrocławskich dokumentów pozwala również konstatować, że przy wystawianiu dokumentów spośród niefunkcyjnych braci obecni byli zakonnicy w dojrzałym wieku, posiadający wyższe święcenia i doświadczenie wielu lat przeżytych w zakonie ${ }^{32}$ lub tacy, którzy wcześniej albo niedługo później sprawowali jakieś urzędy (niekoniecznie we Wrocławiu). Nie było zaś w tym gronie studentów, nowicjuszy i konwersów ${ }^{33}$.

Badania prozopograficzne nad konwentem klasztoru św. Wojciecha dopiero się rozwijają. Piszący na początku XX w. Carl Blasel opracował, głównie na podstawie dokumentów konwentu, listę średniowiecznych przeorów ${ }^{34}$, a Gabriel M. Löhr, wykorzystując podominikańskie kodeksy z Biblioteki Uniwersyteckiej we Wrocławiu, zestawienie studentów wrocławskich, począwszy od lat 20. XV w. ${ }^{35}$ Natomiast

${ }^{30}$ Instructiones Magistri Humberti de officiis ordinis, w: B. Humberti de Romanis Opera de vita regulari, t. 2, wyd. J.J. Berthier, Romae 1889, s. 284-285; tamże s. 285: „Porro in apponendo sigillum conventus in aliqua littera vel charta, in alienatione vel emptione rerum immobilium et mobilium in magna summa, [...] in quibus requiritur de jure consensus capituli, cavere debent ne dent consilium sine licentia et conscientia conventus, nisi forte super his commissionem habeant a conventu: sed referre debent talia ad conventum"; W.A. Hinnebusch, The History, s. 346; R. Kubicki, Środowisko dominikanów, s. 63; K. Kaczmarek, Konwent dominikanów wrocławskich, s. 80-81.

31 Szacunki te mogą być jednak nieścisłe. Przykładowo Wawrzyniec Knote w dokumencie ze stycznia 1405 r. (nr 5) wymieniony jest jako zakrystian, a w dokumencie z marca tr. (nr 6) jego imię jest pozbawione jakichkolwiek dodatkowych informacji. Nie można więc wykluczyć, że niektórzy bracia pełnili jakieś urzędy lub funkcje, ale nie odnotowano tego faktu. Nie biorę pod uwagę dokumentu z listopada $1404 \mathrm{r}$. (nr 4), gdyż jest uszkodzony i nie zachowała się w nim pełna intytulacja. Nie uwzględniam również zaginionego obecnie dokumentu z czerwca $1404 \mathrm{r}$. (nr 3). Do urzędników zaliczam inkwizytorów (Jan Gliwicz był także lektorem, a Tadeusz przeorem). Nie uwzględniam byłych prowincjałów, bo chociaż żyli w klasztorze i cieszyli się niewątpliwym prestiżem oraz szczególnymi prawami, to nie sprawowali żadnego urzędu wewnątrz wspólnoty.

${ }^{32} \mathrm{Na}$ temat wieku zakonników i stażu w zakonie na przełomie XV i XVI w. zob. K. Kaczmarek, Konwent dominikanów wrocławskich, s. 179-198.

${ }^{33}$ Spisy członków wrocławskiego konwentu z końca XV w. pokazują, że bracia niemający wyższych święceń, nowicjusze i konwersi stanowili blisko połowę wspólnoty; K. Kaczmarek, Konwent dominikanów wrocławskich, s. 205-226, $232-241$. Pod koniec XV w. konwersi pełnili funkcje pomocnika zakrystiana (subsacrista, zakrystian był kapłanem) i furtiana; tamże, s. 122, 126, 237, 241. Humbert z Romans dopuszczał konwersów do funkcji furtiana (conversus vel clericus), kapituła generalna z 1268 r. nakazywała „Ad officium sacristie semper aliquis clericus maturus ponatur”; Instructiones, s. 247-253, 274-279; ACGOP, t. 1, s. 143.

${ }^{34}$ C. Blasel, Geschichte von Kirche und Kloster St. Adalbert zu Breslau, Breslau 1912, s. 118. Listę tę można uzupełnić na podstawie informacji pozyskanych z podominikańskich rękopisów. Przed połową 1404 r. przeorem był znany z omawianych dokumentów Marcin Thawraw. Jego imię w tym kontekście zostało wymienione w uszkodzonym dokumencie stanowiącym kartę ochronną kodeksu Biblioteki Uniwersyteckiej we Wrocławiu, rkps I F 653.

35 G.M. Löhr, Breslauer Dominikaner des 15. Jahrhunderts auf auswärtigen Hochschulen, „Archivum Fratrum Praedicatorum”, 13, 1943, s. 169-178; por. M. Bukała, Dominikanie wrocławscy jako studenci i wyktadowcy studiów generalnych prowincji angielskiej w pierwszej połowie XV w., Sobótka, 55, 2000, s. 557-564; S. Zonenberg, Ślazacy z polskiej prowincji dominikańskiej na studiach w Wiedniu w XV i na początku XVI wieku, St. Źródł., 43, 2005, s. 111-124. 
badania K. Kaczmarka dotyczą dopiero ostatniej ćwierci tegoż i pierwszej połowy następnego stule$\mathrm{cia}^{36}$. Znajdujące się w publikowanych dokumentach wykazy dominikanów z wrocławskiego konwentu mogą być bardzo pożyteczne w badaniach nad tymże konwentem. Zasygnalizuję tu tylko niektóre spostrzeżenia. Historycy piszący o wrocławskim klasztorze na przełomie XIV i XV w. nie wykorzystali publikowanych tu dokumentów do badań nad składem osobowym wspólnoty, a jest to na tle dokumentacji innych klasztorów dość wyjątkowa grupa. Dzięki nim otrzymujemy informacje na temat 73 dominikanów, przy czym ponad połowa z nich (64\%) nie była wcześniej odnotowana w elektronicznej bazie danych projektu „Słownik Biograficzny Polskich Mendykantow, t. 1: Dominikanie”. W przypadku pozostałych uzyskujemy nowe dane do ich biografii i kariery zakonnej. Do zestawień lektorów można dodać trzech nowych ${ }^{37}$, a do inkwizytorów - jednego ${ }^{38}$. O Janie de Chomeza wiedziano jedynie, że był lektorem we Wrocławiu w 1404 r., tymczasem dowiadujemy się, że był przeorem w 1390 (nr 1) i lektorem już w 1395 r. (nr 2). Ten sam dokument (nr 2) pozwolił ostatecznie rozwiązać zagadkę końca prowincjalatu Piotra Wasserrabe, który wypełnił swoją kadencję w połowie 1395 i żył we Wrocławiu przynajmniej do 1410 r. (nr 8). Niniejsza grupa zaledwie 10 dokumentów pokazuje, jak duże możliwości badawcze stwarzają niezbadane dotąd zasoby archiwalne.

Przy sześciu z publikowanych tu dokumentów wrocławskiego konwentu zachowały się, w całości lub częściowo, przywieszone pieczęcie. Są to pieczęcie trzech typów: konwentu (nr 1, 2, 5, 8 i 9), przeora (nr 5, 8 i 9) ${ }^{39}$ i prowincjała (nr 2, 5, 6, 8 i 9). Dla uwierzytelnienia dokumentu konieczna była wyłącznie pieczęć konwentu. Przykłady z końca XIV w. (nr 1 i 2) poświadczają, że przeor - chociaż jako pierwszy wymieniony w intytulacji - nie musiał przywieszać swojej pieczęci. Potwierdza to również dokument dominikanów głogowskich z $1401 \mathrm{r}^{40} \mathrm{~W}$ formułach koroboracyjnych sigillum konwentu zawsze wymieniane było przed pieczęcią przeora.

Dokumenty pieczętował również prowincjał, gdy - wizytując lub stale przebywając $\mathrm{w}$ danym klasztorze - występował w charakterze zatwierdzającego czynność dokonana przez braci. W trzech dokumentach (nr 5,6,8) pod zasadniczą treścią dopisana została, za każdym razem podobnie brzmiąca, formuła zatwierdzająca prowincjała. Na dwóch pergaminach z 1405 r. (nr 4 i 5) formuły te pisane są inną ręką niż zasadnicza treść dokumentów, miejscami duktem dosyć niedbałym, ale z pewnością przez tego samego pisarza, co może wskazywać na autograf. Zdaje się, że taka praktyka była charakterystyczna wyłącznie dla prowincjalatu Jana Arnsberga. Nie występuje bowiem na dokumentach potwierdzanych przez innych prowincjałów $\mathrm{z}$ tego okresu ${ }^{41}$

Pieczęć konwentu wrocławskiego (il. 1) ma ostroowalny kształt i wymiary 52 x $33 \mathrm{~mm}$. Jej pole zostało podzielone na dwie części. W górnej przedstawiono popiersie św. Wojciecha w szatach biskupich, w dolnej zaś grupę siedzących postaci w strojach zakonnych ${ }^{42}$. Obydwie części i sceny oddziela wstęga z napisem S. ADALBERTI. Legenda wykonana majuskułą z domieszką liter uncjalnych i półuncjalnych brzmi: S(igillum $) \cdot \operatorname{CONVENT}(u s) \cdot \mathrm{FR}($ atru $) \mathrm{M} \cdot \mathrm{P}($ re $) \operatorname{DICATOR}($ um $) \cdot \mathrm{WRATIZ}($ lavie $)$. Odciski zostały

${ }^{36}$ K. Kaczmarek, Konwent dominikanów wrocławskich. Badania nad pochodzeniem społecznym dominikanek (oraz franciszkanek), w dużej mierze na podstawie informacji z dokumentów konwentu św. Katarzyny, prowadziła H. Kulig, Die Standesverhältnisse des Breslauer Klarenstiftes im Mittelalter, Breslau 1939, s. 55-64.

37 Zob. W. Bucichowski, Lista lektorów dominikańskich prowincji polskiej (od erygowania prowincji do roku 1525), „Przegląd Tomistyczny", 6-7, 1997, s. 45-231; K. Kaczmarek, Szkoły i studia, s. 143, 402-557. Zagadnieniom związanym ze szkolnictwem dominikanów wrocławskich na przełomie XIV i XV w. poświęciłem osobne studium; zob. J. Turek, Próba uruchomienia studium generalnego dominikanów we Wrocławiu na poczatku XV wieku, Rocz. Hist., 84, 2018, s. 171-190.

38 P. Kras, Dominican Inquisitors, s. 295-309.

39 Pieczęć konwentu dawniej przywieszona była także do dok. $\mathrm{nr}$ 4, 6, 7 i 10, a pieczęć przeora do dok. nr 4, 6, 7 i 10. Obecnie na pergaminach widoczne są tylko nacięcia po paskach od tych pieczęci.

${ }^{40}$ AP Wrocław, Rep. 77, nr 3 (nr 5).

${ }^{41}$ Zob. J. Turek, Sigillum provincialatus cum Beata Maria Virgine. Studium pieczęci polskich prowincjałów dominikańskich z XIV i XV wieku, St. Źródł., 54, 2016, s. 72, przyp. 108.

${ }^{42}$ P. Wiszewski widział w tej scenie spowiedź (tenże, Średniowieczna śląska pieczęć klasztorna jako środek przekazu informacji (XIII - pierwsza połowa XVI w.), w: Pieczęć w Polsce średniowiecznej i nowożytnej, red. P. Dymmel, Lublin 1998, s. 20), co jednak wydaje mi się wątpliwą interpretacją. 


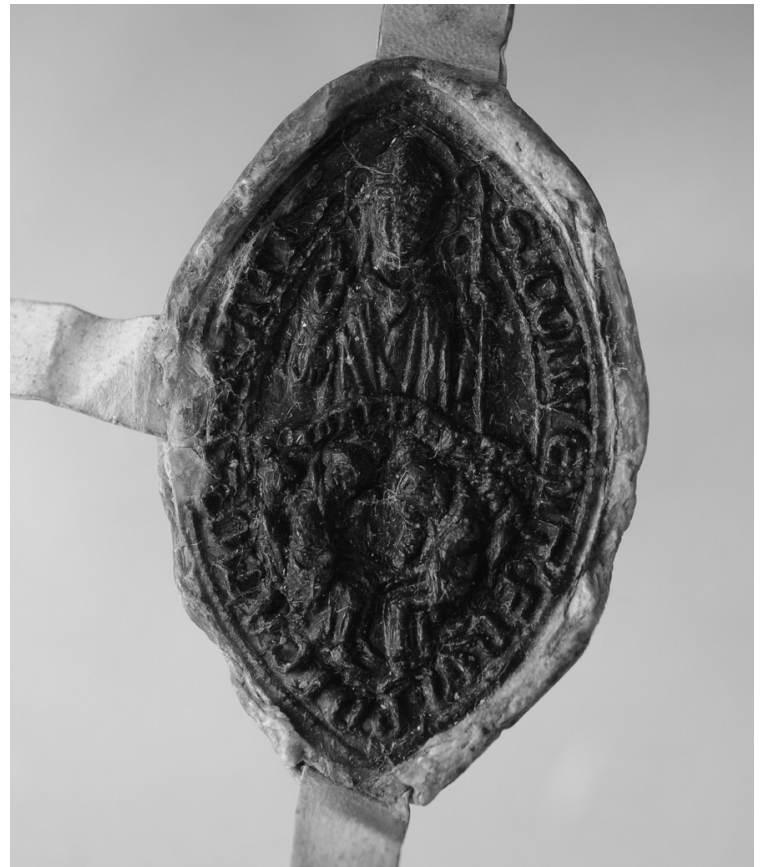

Il. 1. Pieczęć konwentu dominikanów wrocławskich; AP Wrocław, Rep. 58, nr 153, 9 I 1405

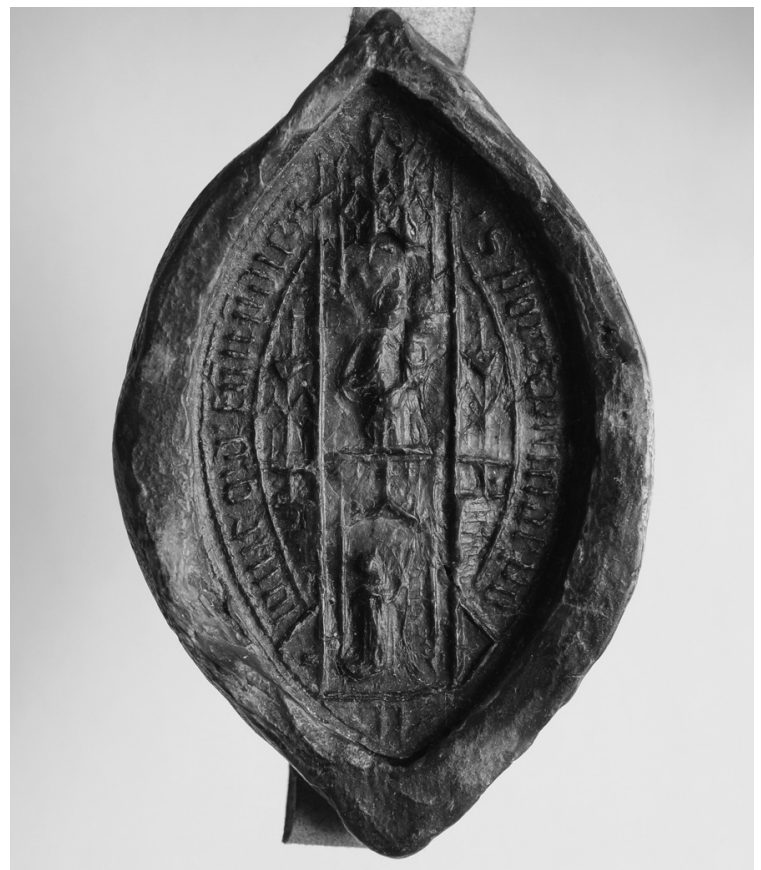

Il. 3. Pieczęć prowincjała dominikanów Piotra Wasserrabe; AP Wrocław, Rep. 58, nr 119, 9 VI 1395

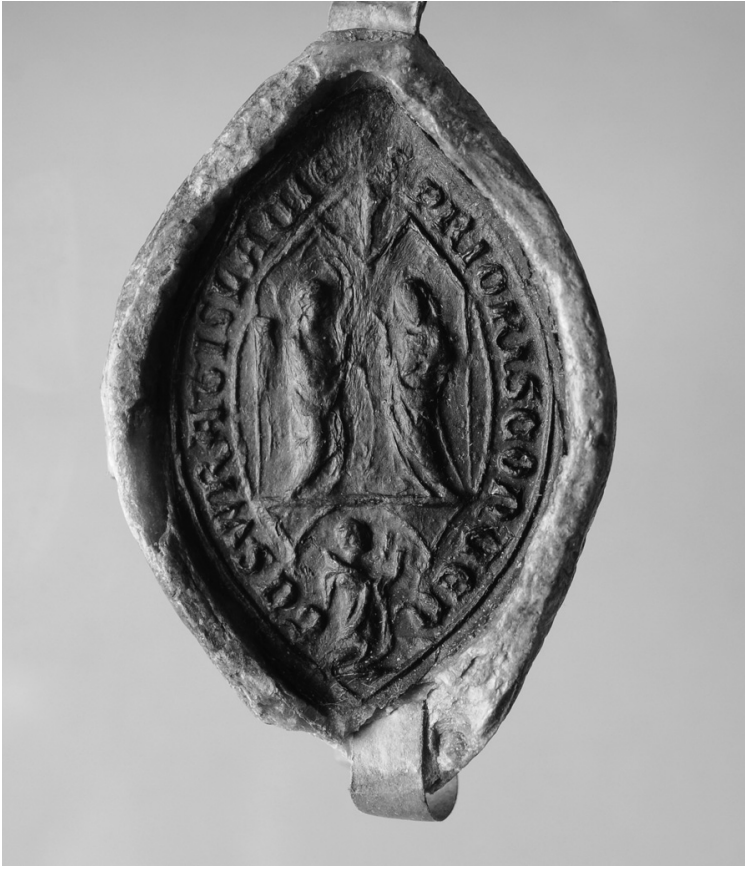

Il. 2. Pieczęć przeora konwentu dominikanów wrocławskich; AP Wrocław, Rep. 58, nr 172, 4 IV 1410

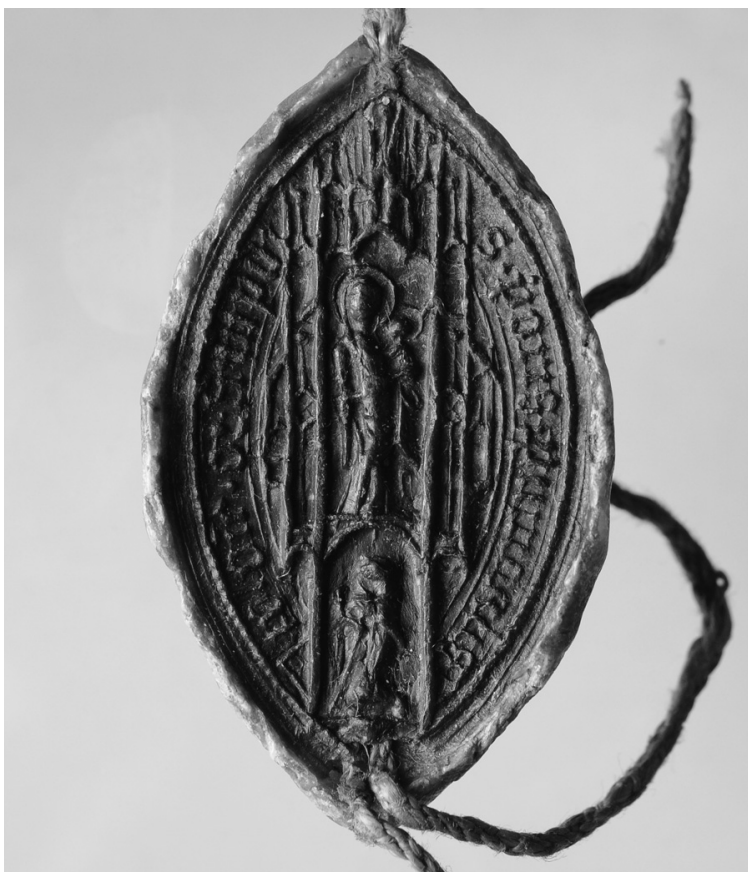

Il. 4. Pieczęć prowincjałów dominikanów Jana Arnsberga i Jan Biskupca; AP Wrocław, Rep. 58, nr 172, 4 VI 1410 
wykonane tym samym typariuszem w zielonym wosku i umieszczone w miskach ochronnych z wosku naturalnego, przywieszonych do dokumentów na paskach pergaminowych. Cztery egzemplarze (nr 2, 5, 8 i 9) zachowane są w dobrym stanie. Odciski z 1390 i 1424 r. (nr 1 i 10) odpadły, pozostawiając jedynie miski ochronne, a odcisk z 1395 r. (nr 2) ma częściowo uszkodzoną legendę. Mosiężny tłok, datowany na XIV w., zachował się w zbiorach Muzeum Narodowego we Wrocławiu ${ }^{43}$.

Pieczęć przeora (il. 2) ma ostroowalny kształt i wymiary 48 x $31 \mathrm{~mm}$. W jej polu umieszczono scenę Zwiastowania. Poniżej, w niszy, jest klęcząca postać adoranta w szatach zakonnych. Legenda wykonana majuskułą z domieszką liter uncjalnych i półuncjalnych brzmi: S(igillum) PRIORIS CONVEN / TUS WRATISLAVIE. Odciski zostały wykonane tym samym typariuszem w zielonym lub brunatnym wosku i umieszczone w miskach ochronnych z wosku naturalnego, przywieszonych do dokumentów na paskach pergaminowych. Dwa zachowane egzemplarze są w dobrym stanie (nr 5 i 8), natomiast odcisk z 1415 r. (9) jest poważnie uszkodzony. Ten sam typariusz był używany przez różnych przeorów, co wskazuje na charakter urzędowy pieczęci ${ }^{44}$.

Przy pięciu z publikowanych dokumentów znajdują się też pieczęcie prowincjała, odciśnięte w wosku dwoma różnymi typariuszami - za pomocą pierwszego (il. 3) wykonano pieczęć prowincjała Piotra Wasserrabe (nr 2), drugim (il. 4) posługiwali się Jan Arnsberg i Jan Biskupiec (nr 5, 6, 8 i 9). Obydwie pieczęcie mają ostroowalny kształt i wymiary $60 \times 33 \mathrm{~mm}$. W ich polach umieszczono Matkę Boską z Dzieciątkiem. Pieczęcie prowincjałów szczegółowo omówiłem w osobnym studium ${ }^{45}$.

${ }^{43}$ Zob. Gloria Deo. Rzemiosło sakralne, t. 2, red. M. Korżel-Kraśna, Wrocław 2010, s. 129, nr 137.

${ }_{44}$ Zob. J. Turek, Sigillum provincialatus, s. 64.

${ }^{45}$ Tamże, s. 59-83. 


\section{Aneks}

\section{Dokumenty wystawione przez konwent dominikanów wroclawskich w latach 1390-1424}

Wydane poniżej dokumenty opracowano zgodnie z zaleceniami instrukcji wydawniczej Adama Wolffa ${ }^{1}$. W przypadku dwóch dokumentów niemieckich skorzystano również z części zaleceń Johannesa Schultzego $^{2}$. Tekst został transliterowany z zachowaniem $v$ i $u$ bez względu na wartość fonetyczną. Zdecydowano się na zapisywanie $c z$ na początków wyrazów jako $z$. Duże litery zastosowano na początku zdań, w imionach oraz nazwach własnych i geograficznych, a także nazwach świąt. W przypisach rzeczowych zamieszczono podstawowe informacje na temat rozpoznanych zakonników, odsyłając do istniejących już biogramów. Osoby skądinąd nieznane pozostawione zostały bez objaśnienia. Za pomoc w przygotowaniu tekstu do edycji pragnę w tym miejscu podziękować p. Magdalenie Markiewicz.

${ }^{1}$ A. Wolff, Projekt instrukcji wydawniczej dla pisanych źródeł historycznych do połowy XVI wieku, St. Źródł., 1, 1957, s. $155-180$.

2 J. Schultze, Richtlinien für die äußere Textgestaltung bei Herausgabe von Quellen zur neueren deutschen Geschichte, „Blätter für deutsche Landesgeschichte", 98, 1962, s. 1-11. 
Przeor Jan z Chomiaży i bracia z klasztoru św. Wojciecha we Wrocławiu potwierdzaja, że Andrzej Kusseldis przekazal konwentowi 100 grzywien groszy czeskich i zobowiazuja sie odprawiać msze przy oltarzu Krzyża Świętego w kościele św. Katarzyny za dusze darczyńcy i jego rodziny

Or.: AP Wrocław, Rep. 58, nr 103. Pergamin $228 \times 132+27$ mm, dobrze zachowany. Na pasku pergaminowym uszkodzona pieczęć konwentu. Na odwrociu streszczenia (XV-XVIII w.) oraz numery inwentarzowe i pieczęć archiwum z XIX w.

Reg.: Katalog dokumentów przechowywanych w archiwach państwowych Dolnego Śląka, t. 6: 1380-1391, oprac. M. Chmielewska, Wrocław 1995, nr 580

Vor allen den, di desin brif sehen, horen adir lesen, so bekenne wir hernoch geschre|bin bruder der Prediger orden des closters zu sinte Albrecht czu Breslaw ${ }^{1}$ : bruder Jo|hannes Chomesa ${ }^{2}$ prior, bruder Henricus Swenkynvelt ${ }^{3}$ subprior, bruder Andreas von Berlyn ${ }^{4} \mid$ lesemeister of dem thume, Augustinus ${ }^{5}$ cursor, bruder Martinus Thuro 6 , bruder Michael Coppericz, bruder Vincentius ${ }^{8}$ der iuncfrawen bichtiger $\mathrm{zu}$ sinte Katherin ${ }^{9}$ unde andir bruder des covents, das wir uns vorbundin habin und globit mit gutem willen unbetwungin, das wir schuldig sin von rechte $\mathrm{zu}$ halden und $\mathrm{zu}$ lesen $\mathrm{zwu}$ ewege messin alle tage ane gesang in der kirchen zu sinte Katherin zu Breslaw in deme kore obir des heilegin Crucis altar vor Andris Kusseldis sele und siner husvrawen sele, siner kinder, siner eldern und siner nochkomelinge selen und vor siner bruder sele, durch irs almosin wille, das se uns dortzu gegeben haben, mit namen hundirt marg bemischer grosschin polonischer zal, di uns ganz und gar betzalt sin mit gereiten phenningen, und ap do wedir imant welden sprechen ap sichs vor ierte adir vor aldirte und welde sprechen, wir wesin nicht do von worwunne, sulle wir se halden, se sint von gonst gelesen und gehalden und der recht wedir recht, sunder wir halden und lesen se von rechte durch irs almosin wille, das se uns dortzu gegebin habin, das wir wissentlichen unde offenberlichen an unser gebude und andir notdorftekeit geleyt habin. Dorumme so halde wir se von rechte no und eweclichen in alle der weise also vor geschrebin stet. Des zu grosiir zichirheit und bebeutuns und bestatunge unser vorbindunge habe wir desin keigenwortegin brif vorsegilt mit unsers convents anhangindingen ingesegil. Noch Gotis geburt tusunt drihundirt iar in dem newntzegisten iare an dem tage also unser Herre besnetin wart.

\footnotetext{
${ }^{1}$ Klasztor dominikanów św. Wojciecha we Wroctawiu, ufundowany w $1226 r$.

2 Jan z Chomiąży, lektor w 1395 i 1404 r. (nr 2 i 3); zob. W. Bucichowski, Lista lektorów dominikańskich prowincji polskiej (od erygowania prowincji do roku 1525), ,Przegląd Tomistyczny”, 6-7, 1997, s. 139, nr 492; K. Kaczmarek, Szkoty i studia polskich dominikanów w okresie średniowiecza, Poznań 2005, s. 470, nr 155. Chomiąża, miejscowość na Dolnym Śląsku w pow. średzkim.

${ }^{3}$ Henryk Schwenkenfeld, w latach 70. XIV w. wybrany na przeora w Gtogowie; Zbiór formul zakonu dominikańskiego prowincji polskiej z lat 1338-1411, wyd. J. Woroniecki, J. Fijałek, AKH, t. 12, 1919-1938, cz. 2, nr 81. Makowice (Schwenkenfeld), miejscowość na Dolnym Śląsku w pow. świdnickim, pochodziła z niej znana rodzina rycerska.

${ }^{4}$ Tożsamy z Andrzejem Bellinem, lektorem w Legnicy w 1378 r.; zob. W. Bucichowski, Lista lektorów dominikańskich, s. 80, nr 44; K. Kaczmarek, Szkoty i studia, s. 403, nr 5. Może chodzi o Berlin, miasto w Brandenburgii, lokowane w XIII w., na przełomie XIV i XV w. zależne od królów czeskich.

${ }^{5}$ Augustyn, lektor artium i mistrz studentów w Krakowie w 1378 r. Lektor wroctawski w 1404, 1405, 1407, 1410, (nr 3-8, 10) i 1427 r.; zob. W. Bucichowski, Lista lektorów dominikańskich, s. 86, nr 76; K. Kaczmarek, Szkoły i studia, s. 404, nr 7 i s. 436, $n r 39$.

${ }^{6}$ Marcin Thawraw (Thuro, Thuraw), brat w klasztorze św. Wojciecha w 1395 i 1410 r. (nr 2 i 8). Przeor ok. 1404 r.; Biblioteka Uniwersytecka we Wrocławiu, rkps I F 653, karta ochronna. Turów, miejscowość na Dolnym Śląsku w pow. wrocławskim.

${ }^{7}$ Kuppritz, miejscowość we wschodniej Saksonii, w pow. Bautzen (Budziszyn) lub Kopice na Opolszczyźnie w pow. brzeskim.

${ }^{8}$ Wincenty, brat w klasztorze św. Wojciecha w 1407 r. (nr 7).

${ }^{9}$ Klasztor dominikanek św. Katarzyny we Wrocławiu, ufundowany pod koniec XIII w.
} 
Przeor Piotr Pulsnicz i bracia z klasztoru św. Wojciecha we Wrocławiu potwierdzaja, że Henryk Weysse wraz z żona Dorota podarowali klasztorowi srebrna pozłacana monstrancję i zobowiazuja się używá jej podczas wymienionych świąt oraz odprawiać msze za dusze darczyńców

Or.: AP Wroctaw, Rep. 58, nr 119. Pergamin $435 \times 250+54$ mm, dobrze zachowany; ozdobny inicjat „I” $w$ ksztatcie ryby do 1/2 wysokości tekstu. Na paskach pergaminowych pieczęcie prowincjata $i$ konwentu. Na odwrociu znajdują się streszczenia (XV-XVIII w.) oraz numery inwentarzowe i pieczęć archiwum z XIX w.

Reg.: Katalog dokumentów przechowywanych $w$ archiwach państwowych Dolnego Ślaska, t. 7: 1392-1400, oprac. R. Stelmach, Wroctaw 1993, $n$ r 186

Lit.: J. Heyne, Dokumentirte Geschichte des Bisthums und Hochstiftes Breslau, t. 2, Breslau 1864, s. 722

In nomine Domini, amen. Quoniam actibus humanis varietate perplexis multiformi, satore zyzaniorum hostili nequiter suggerente, peccata quam plurima adversari solent, quibus ordo congruus con|funditur ac res vigore suo dampnabiliter defraudantur. Expedit eatenus rebus dignis memoria perhenni sui pro constancia verorum testimonia apponere sub scripture notamine pro cautela. I Sane igitur nos fratres infrascripti, videlicet frater Petrus Pulsnicz ${ }^{1}$ prior, frater Petrus ${ }^{2}$ penitenciarius domini pape, frater Paulus Mundyl ${ }^{3}$ lector, frater Johannes de Chomeza ${ }^{4}$ lector, frater Martinus Thuraw ${ }^{5}$, frater Micha|hel subprior, frater Michael confessor, frater Nicolaus confessor, frater Mathias Beruch $z^{6}$, frater Nicolaus Faber, frater Laurencius ${ }^{7}$, frater Johannes Domaskirche ${ }^{8}$ ceterique fratres conventuales monasterii ad sanctum Adalbertum in Wratislavia, ordinis Fratrum Predicatorum, more solito ad sonum campane capitulariter congregati, speciali tamen licencia ordinis nostri fratris Petri Wassirrabe provincialis, protunc presencialiter existenti ibidem, de suo scitu, consensu ac aliorum dicti monasterii seniorum assensu et voluntate, tenore [presentium], quibus expedit, recognoscimus universis, quod pro diversis promocionum generibus ac elemosinarum largicionibus honesti viri Heynrici Weysse ac consorti[s] eius Dorothee Deuczlenderinne defuncte dicte civitatis, nobis tam gratanter ac benivole ac dicto nostro monasterio sepe et sepius exhibitis et in posterum divino instinctu, ut speramus, exhibendis, signanter unam monstranciam argenteam deauratam conventui prefato obtulit pariter et donavit ob reverenciam sacramentum Corporis Christi in ea deferendum ac collocandum, desiderans predictam monstranciam cum sacramento singulis annis in ipsius sacramenti festo et feriis secundis post dominicam Palmarum in processione reverenter ob devocionem populi ad sorores nostri ordinis dicte civitatis deportari. Nos igitur eorum gratitudini ac affeccioni, videlicet prenominati viri Heynrici Weysse ac eius consorti[s] Dorothee Deuzlenderinne defuncte, quas ad nos et ad dictum nostrum, ut premittitur, monasterium fere inde gessisse dinoscimus, vicem rependere occurendo cupientes, volentes eorum intencionem adimplere et eorum

\footnotetext{
${ }^{1}$ Piotr Pulsnicz (z Pełcznicy), może wcześniej byt inkwizytorem, gdyż posiadał księge zawierająca kompilację tekstów dotyczacych herezji; zob. A. Patschovsky, Spuren böhmischer Ketzerverfolgung in Schlesien am Ende des 14. Jahrhunderts, w: Historia docet, Praha 1992, s. 357-387. Petcznica, miejscowość na Dolnym Śląsku w pow. wrocławskim.

2 Piotr z Chomiazzy, prowincjat w latach 1356-1370 i 1382-1385, a od 1389 r. penitencjarz papieski; zob. R.-J. Loenertz, Une ancienne chronique des provinciaux dominicains de Pologne, „Archivum Fratrum Praedicatorum”, 21, 1951, s. 33, 35; W. Bucichowski, Lista lektorów dominikańskich, s. 191, $n r 880$.

${ }_{3}^{3}$ Pawet Mundil, lektor w 1404 (nr 3 i 4) i 1405 r. (nr 5 i 6); zob. W. Bucichowski, Lista lektorów dominikańskich, s. 186, nr 841; K. Kaczmarek, Szkoty i studia, s. 539, nr 431.

4 Zob. $n r$ 1, przyp. 2.

${ }^{5}$ Zob. nr 1, przyp. 6.

${ }^{6}$ Maciej Berusch (Beruchz, Berusz), brat w klasztorze św. Wojciecha w 1404, 1405 i 1407 r. (nr 3-7). Przeor w 1396 r. (zob. $n r 6)$.

${ }^{7}$ Wawrzyniec, brat w klasztorze św. Wojciecha w 1405 r. (nr 6). Terminarz w 1407 r. (nr 7).

${ }^{8}$ Domaniów (Domaskirche), miejscowość na Dolnym Ślasku w pow. oławskim.
} 
affeccionem devotam effectam officiatione prebere, unde nos fratres suprascripti sepedicti monasterii et ordinis promittimus et temporibus perpetuis nos obligamus singulis feriis quartis IIII ${ }^{\text {or }}$ temporum anni missam de Corpore Christi cantandam et presencialiter dictam monstranciam cum sacramento vel aliis reliquiis in altari residere ibidem et sequentibus proximis sextis feriis, dummodo festum quodcumque sollempne occurendo non impediat, quod si sit proxima feria VI in remedium animarum dictarum, videlicet Heynrici Weisse ac Dorothe Deuczlenderinne consorti[s] eius et pro quibus intendunt, missam pro defunctis cum vigiliarum sollempniis peragendam. Et ne memoria benefactorum preteritorum oblivioni operum detur volumus, ut anime premissorum benefactorum ante missam coram populo recitentur ac eorum devocionibus recommendentur. Ne igitur antedicta monstrancia per quamcumque negligenciam voluntariam perderetur seu alienaretur vel inpignoraretur in preiudicium testatorum seu quovismodo amoveretur, seclusis casibus, videlicet violencia dominorum et heredum terrarum ac aliis accidentibus generalibus, ut puta ignis et inpressionibus fulminis, aliis non obstantibus, volumus nos fore [et] esse subiectos sentencia excommunicacionis nostri ordinarii iudicis provincialis, qui est vel qui pro tempore erit, quam nos voluntarie subicimus per presentes, si a noticia alienacionis infra spacium sex mensium ad septuaginta duarum marcarum, que dicta monstrancia computa fuit, dum ordini et conventui fuit donata, consimilis in pondere et valore loco dicte monstrancie non fuit comparata vel iuxta intencionem executorum et provisorum ad hoc expositorum ${ }^{\mathrm{a}}$ et rogatorum ${ }^{\mathrm{b}}$, qui merito nos et nostrum conventum, si casus accideret, habent monere iuxta eorum disposicionem et voluntatem, vel qui litteram habuerint loco executorum. Ut autem omnia hec premissa robur firmitatis perpetuum obtineant, presentem litteram sigillorum $^{\mathrm{c}}$ officii provincialatus et conventus munimine fecimus roborari, promittentes ac summo desiderio cupientes ea, ut premittitur, a nostris successoribus, pro tempore qui fuerint, nullomodo infringi. Datum et actum feria IIII in vigilia Corporis Christi, anno Domini millesimo $\mathrm{CCC}^{\circ} \mathrm{XCV}^{\circ}$.

\footnotetext{
a expositi.

${ }^{b}$ rogati.

${ }^{c}$ sigillis.
} 
Piotr Wasserrabe, wikariusz prowincjała dla kontraty ślaskiej oraz przeor Tadeusz i bracia z klasztoru św. Wojciecha we Wroctawiu potwierdzaja nadanie klasztorowi 4 grzywien czynszu rocznego poczynione $w$ testamencie [Katarzyny] Jokoschynne

Or.: zaginiony (dawna sygnatura AP Wrocław, Rep. 57, $n$ r 100)

Reg.: AP Wrockaw, Rep. 135, t. 50, s. 529-530, nr 100 (regest z 1819 r.)

Lit.: J. Kloczowski, Dominikanie polscy na Ślasku w XIII-XIV wieku, Lublin 1956, s. 196; K. Kaczmarek, Konwent dominikanów wrocławskich w późnym średniowieczu, Wrocław 2008, s. 22; tenże, Szkoły i studia polskich dominikanów w okresie średniowiecza, Poznań 2005, s. 143, 470, 539; A. Zajchowska, Franciszek Oczko i początki reformy obserwanckiej w polskiej prowincji dominikanów, „Średniowiecze Polskie i Powszechne", 4, 2012, s. 205

Uw.: Zapisy testamentu zostaly potwierdzone w dokumencie z 29 XII 1424 r.; zob. $n r 10$

Frater Petrus Wasserrabe ${ }^{1}$, sacrae theologiae professor nec non et vicarius provincialis Poloniae per contratam Slezyae, Thaedeus ${ }^{2}$ prior Wratislaviensis, Johannes Gleywycz ${ }^{3}$ inquisitor Slezyae, Augustinus ${ }^{4}$ lector, Paulus Mundel ${ }^{5}$ lector, Johannes de Comeza ${ }^{6}$ lector, Mathyas ${ }^{7}$ cursor domus, Mathyas Barusch ${ }^{8}$, Johannes de Rathybor ${ }^{9}$ subprior domus, Maternus confessor sororum, Nicolaus Felcz ${ }^{10}$ portarius ${ }^{\mathrm{a}}$, Laurentius Knoth ${ }^{11}$ sacrista, Nicolaus Taczolt ${ }^{12}$ procurator conventus ceterique fratres conventus et monasterii sancti Adalberti in Wratyslawya, ordinis Fratrum Praedicatorum, recognoscunt, quod relicta Jokaschynne, civissa in Wratislavia, pro remedio animae suae, mariti sui, filii sui filiarumque suarum donavit nomine perpetui testamenti conventui eodem 4 marcas annui census in et super bonis omnibus Johannis Rothe, civis Wratislaviensis, quamlibet marcam census pro 12 marcis comparatam, ad reemendum pro 48 marcis grossorum Boemicalium numeri Polonicalis et pagamenti, ad anniversarium celebrandum (conditionibus aliis intus adiectis). Datum Wratislaviae, anno Domini 1404, feria 3 infra octavam Corporis Christi.

${ }^{a}$ W tekście błędnie precarius.

${ }^{1}$ Piotr Wasserrabe, prowincjat w latach 1385-1395, w latach 1392-1393 generat bezskutecznie próbowat usunać go z tego urzędu. Od 1401 r. mistrz teologii; zm. po 4 IV 1410 (nr 8); zob. R.-J. Loenertz, Une ancienne chronique, s. 35-36; W. Bucichowski, Lista lektorów dominikańskich, s. 192, nr 889; K. Kaczmarek, Szkoły i studia, s. 422, nr 82.

${ }^{2}$ Tadeusz, przeor $w$ 1405, 1407 i $1415 \mathrm{r}$. (nr 5-7, 9). W 1415 r. także inkwizytor. Może tożsamy z przeorem poznańskim z 1403 i 1413 r.; zob. K. Kaczmarek, Konwent dominikanów poznańskich średniowieczu, „Ecclesia. Studia z Dziejów Wielkopolski", 1, 2003, s. 47.

${ }^{3}$ Jan Gliwicz, w latach 80. XIV w. student w Kolonii. Od 1384 r. lektor w Brzegu. Ok. 1396 r. mianowany przez prowincjała inkwizytorem, dwukrotnie zatwierdzany przez biskupa wrocławskiego w 1397 i 1404 r. Lektor w 1415 r. (nr 9); zob. W. Bucichowski, Lista lektorów dominikańskich, s. 140, nr 496; K. Kaczmarek, Szkoły i studia, s. 409, nr 26; P. Kras, Dominican Inquisitors in Medieval Poland $\left(14^{\text {th }}-15^{\text {th }}\right.$ c.), w: Praedicatores inquisitores, $t$. 1: The Dominicans and the Medieval Inquisition, red. W. Hoyer, Roma 2004, s. 299-300, nr 14. Gliwice, miasto na Górnym Ślasku, lokowane w XIII w., stolica księstwa gliwickiego.

${ }_{4}^{4}$ Zob. nr 1, przyp. 5.

${ }_{5}$ Zob. $n r$ 2, przyp. 3.

${ }^{6}$ Zob. $n r$ 1, przyp. 2.

${ }_{7}^{7}$ Maciej z Brześcia, kursor w 1404 i 1405 r. (nr 4-6).

${ }^{8}$ Zob. $n r$ 2, przyp. 6.

${ }^{9}$ Jan z Raciborza (zw. Zephiri), student w Krakowie w 1378 r. W 1382 r. brat w Raciborzu. Subprzeor wroctawski $w 1405$ r. (nr 5, 6); zob. K. Kaczmarek, Szkoły i studia, s. 410, nr 30. Racibórz, miasto na Górnym Ślasku, lokowane w XIII w., stolica księstwa raciborskiego. Od połowy XIII w. znajdowat się tutaj klasztor dominikanów św. Jakuba, a od ok. 1299 r. dominikanek Ducha Świętego.

${ }_{10}$ Mikotaj Felcz (Falczsch), furtian w 1404 (nr 4). Brat w klasztorze św. Wojciecha w 1405 r. (nr 5 i 6).

11 Wawrzyniec (Lorenz) Knote, zakrystian w 1404, 1405, 1407 i 1410 r. (nr 4, 5, 7, 8).

12 Mikołaj Taczolt, w 1401 r. adwokat konsystorza wroctawskiego, Archiwum Diecezjalne w Sandomierzu, perg. nr 29. Brat w klasztorze św. Wojciecha w 1407 r. (nr 7). 
Przeor Tadeusz i bracia z klasztoru św. Wojciecha we Wroctawiu potwierdzaja nadania poczynione $w$ testamencie Matgorzaty Pepylwiczinne i zobowiazuja się do modlitw w intencji ofiarodawczyni

Or.: AP Wroctaw, Rep. 57, nr 52 (104a). Pergamin $275 x 215+31 \mathrm{~mm}$, w ztym stanie, brakuje niemal 1/3 pergaminu po prawej stronie, uszkodzenia na zgięciach, dziura na górze dokumentu; ozdobny inicjat „Q” do wysokości $1 / 3$ tekstu. Na zakładce nacięcia po dwóch paskach od pieczęci. Na odwrociu streszczenie (XV w.) oraz naklejki z numerami inwentarzowymi i pieczęć z XIX w.

Quoniam decursu temporum ex rerum varietate multiplici humane fragilitatis facil[1]ime proprie[?] et memorie [a] | consuevit muniri presidio, hinc est, quod nos, fratres ordinis Fratrum Predicatorum conventus seu monasterii [sancti Adalberti in Wratislavia] | frater Thadeus ${ }^{1}$ prior, frater Petrus Wassirrabe $^{2} \mathrm{~s}[\mathrm{ac}] \mathrm{re}^{\mathrm{b}}$ theologie professor, frater Paulus Mundil ${ }^{3}\left[{ }^{\mathrm{a}}\right]$ [frater] | Petrus Gerstman ${ }^{4}$ lector domus, frater Mathias de Bresth ${ }^{5}$ cursor, frater Mathias Berusch ${ }^{6}$, frater Johannes ${ }^{7}\left[{ }^{a}\right]$ [confes]sores sororum, frater Nycolaus Felczsch ${ }^{8}$ portar[ius], frater Wenczeslaus de Legnicz' frater Michael de Nova Civ[itate $]^{10}\left[{ }^{a}\right]$ frater Franciscus Glocz ${ }^{11}$, frater Laurencius Knote ${ }^{12}$ sacris[ta] ceterique fratres dicti conventus et ordinis universis tam presen[tibus], [quam] fut[uris], [recognoscimus quod] ad nostram presenciam honesta ac devota domina Margaretha dicta Pepylwiczinne, non coacta nec compulsa onq[....] [sana mente] et corpore, illo procul dubio inspirata Spiritu [S]an[cto] ${ }^{c}$ Dei aguntur filii deliberato animo sanoque preconcepto ac prehabito con[.]ili[... [ ["] progenitorum remedium obtulit et donavit at[......] ${ }^{\mathrm{d}}$ veri ac legitimi testamenti irrevocabiliter legavit libere ac vol[enter] [a] census Polonicalis numeri et Bohemicalis pagamenti triginta videlicet marcas grossorum eiusdem numeri et pagamenti [a] emere promittimus una cum tutoribus, quos $[\ldots . .]^{\mathrm{e}}$ hoc elegit ubicumque et quicumque poterimus tres marcas annui census de $\left[{ }^{a}\right][\ldots \ldots$.$] rare omnino tum sub fide sua, quatenus { }^{\mathrm{f}}[\ldots \ldots \ldots \ldots \ldots \ldots \ldots \ldots \ldots]^{\mathrm{f}}$ frater

${ }^{a}$ Czesść pergaminu (niemal 1/3) po prawej stronie została oderwana i w każdym wierszu brak ok. 6 końcowych wyrazów.

${ }^{b}$ Dziura $w$ pergaminie.

${ }^{c}$ Dziura $w$ pergaminie.

${ }^{d}$ Uszkodzone na zgięciu pergaminu.

${ }^{2}$ Zatarte na zgięciu.

ff Zatarte na zgięciu.

${ }^{1}$ Zob. nr 3, przyp. 2.

2 Zob. nr 3, przyp. 1.

3 Zob. nr 2, przyp. 3.

${ }^{4}$ Piotr Gerstman, w 1378 r. student w Świdnicy. Lektor wrocławski w 1405, 1407 i 1410 r. (nr 5-8). Przeor w latach 1416-1419. W 1417 r. wikariusz kontraty ślaskiej w ramach separatystycznej prowincji Dolnych Niemiec; zob. W. Bucichowski, Lista lektorów dominikańskich, s. 190-191, nr 878; K. Kaczmarek, Szkoty i studia, s. 422, nr 80.

${ }_{5}^{5}$ Zob. nr 3, przyp. 7. Brześć Kujawski, miasto na Kujawach, lokowane w XIII w. W połowie XIII w. w mieście ufundowany został dominikański klasztor św. Michała.

${ }^{6}$ Zob. nr 2, przyp. 6.

7 Może tożsamy z którymś bratem o tym imieniu.

${ }^{8}$ Zob. $n r$ 3, przyp. 10.

9 Wacław z Legnicy, w 1384 r. skierowany do nieznanego konwentu; T. Gałuszka, Fragmenty czternastowiecznych akt kapitut prowincjalnych dominikanów polskich w zbiorach Bayerische Staatsbibliothek w Monachium. Kapituła prowincjalna w Opatowcu w 1384 roku, St. Źródt., 51, 2013, s. 119. Legnica, miasto na Dolnym Śląsku, od XIII w. stolica księstwa legnickiego. $W$ drugiej połowie XIII w. w mieście ufundowany zostat dominikański klasztor Krzyża Świętego.

${ }^{10}$ Michat z Nowego Miasta, brat w klasztorze św. Wojciecha w 1405 r. (nr 5-6). Subprzeor w 1407 r. (nr 7). Nowe Miasto, dzielnica Wrocławia położona za murami miasta.

11 Kłodzko, miasto na Dolnym Śląsk, lokowane w XIII w.

12 Zob. nr 3, przyp. 11. 
Johannes Hollant ${ }^{13}\left[{ }^{\mathrm{a}}\right]^{\mathrm{g}-}[\ldots \ldots \ldots]^{-\mathrm{g}}$ marcas annis singulis tres $[\ldots \ldots]$ liquis ${ }^{\mathrm{h}}$ ipsam et vite sue tempore, tollere et ad suos $\mathrm{u}[.$. ]ila [a] [...]utrorum, quia tamen due marce, quas dictus frater Johannes Hollant tollere debet, quam eciam alie tres, quas prefata domina Margaretha [a] devolvi debent pertinereque conventum immediate. Nos igitur tantis caritatis eius beneficiis utpote non $\left.{ }^{\mathrm{a}}\right]$ corrundere retribucionibus secundum ipsius sepe dicte Margarethe affectum ac desiderium nos nostrosque posteriores [a] legendum per sua suorumque progenitorum salute ebdomadibus singulis in altari, quod est situm in acie capelle [a] videlicet feria secunda, secundam feria sexta et tertiam sabbato. Insuper, cum dictam dominam Margaretham ex hac lu[cem] [a] lectionum[?] et missa pro defunctis ob anime sue refrigerium una cum predictis omnibus perpetuis temporibus promittimus inviola[biliter] [ $\left.{ }^{a}\right]$ autem predictum ipsius peragetur aniversarium prior ille existens tempore fratribus de eisdem pecuniis adminus pro fertone [ ${ }^{a}$ ] [In quorum] omnium robur et testimonium sigillum nostri conventus ac eciam sigillum officii prioratus presentibus decrevimus [a] [Datum in] conventu, anno Domini $\mathrm{M}^{\mathrm{o}}$ quadringentesimo quarto, quarta die mensis novembris.

\footnotetext{
g-g Zatarte na zgięciu.

${ }^{h}$ Niewyraźne na zgięciu.

13 Jan Hollant, subprzeor w 1415 r. (nr 9).
} 
Przeor Tadeusz i bracia z klasztoru św. Wojciecha we Wrocławiu potwierdzaja, że siostry z klasztoru św. Katarzyny, jako egzekutorki testamentu Doroty Rusinne, przekazały im 48 grzywien groszy czeskich, za które zakupiono 4 grzywny czynszu. Zakonnicy zobowiąuja się odprawiać codziennie msze święte przy ołtarzu Bożego Ciała w kościele św. Katarzyny. Dokument potwierdza prowincjat Jan Arnsberg

Or.: AP Wrocław, Rep. 58, $\mathrm{nr}$ 153. Pergamin $353 \times 118+31 \mathrm{~mm}$, dobrze zachowany, ozdobny inicjat „I” do wysokości 1/2 tekstu. Na paskach pergaminowych pieczęcie konwentu, prowincjała (bardzo uszkodzona) i przeora. Na odwrociu streszczenia (XV-XVIII w.) oraz numery inwentarzowe i pieczęć archiwum z XIX w.

Lit.: J. Heyne, Dokumentierte Geschichte, t. 2, s. 722-723; J. Fijałek, Wstę, w: Zbiór formut zakonu dominikańskiego prowincji polskiej z lat 1338-1411, wyd. J. Woroniecki, J. Fijatek, AKH, t. 12, 1919-1938, cz. 2, s. 224; J. Kłoczowski, Dominikanie polscy na Ślasku w XIII-XIV wieku, Lublin 1956, s. 90

In nomine Domini, amen. Quoniam ea, que fiunt in tempore, ne simul labantur cum tempore, necesse est litterarum presidio et sigillorum adminiculo perhennari. Exhinc nos fratres, videlicet Thadeus ${ }^{1}$ prior, Petrus Wassir|rabe ${ }^{2}$ sacre theologie professor, Johannes Glywicz ${ }^{3}$ inquisitor Zlesie, Paulus Mundil ${ }^{4}$ lector, Augustinus ${ }^{5}$ lector, Petrus Gerstman ${ }^{6}$ lector domus, Mathias de Brest ${ }^{7}$ cursor, Johannes de Rathibur ${ }^{8}$ | supprior, Mathias Beruchz ${ }^{9}$, Wencesslaus Sparer ${ }^{10}$, Martinus ${ }^{11}$, Johannes Patchein ${ }^{12}$ confessor sororum, Andreas Swydenicz ${ }^{13}$ magister studentium, Nicolaus Falcz ${ }^{14}$, Thomasko ${ }^{15}$, Michael de Nova Civitate $^{16}$, Laurencius $\mid$ Knote $^{17}$ sacrista ceterique fratres conventus et monasterii sancti Adalberti, ordinis Fratrum Predicatorum, in Wratislavia recognoscimus universis et singulis presens scriptum inspecturis nos a religiosis et devotis Katherina de Nyza ${ }^{18}$ priorissa et Katherina Vaitinne ${ }^{19}$ sororibus conventus et monasterii sancte Katherine, ordinis Predicatorum, tamquam executricibus testamenti ex parte pie memorie Dorothee Rusinne ${ }^{20}$ sororis conventus et ordinis eorundem testate, XLVIII marcas grossorum

1 Zob. nr 3, przyp. 2.

2 Zob. nr 3, przyp. 1.

3 Zob. nr 3, przyp. 3.

${ }_{4}^{4}$ Zob. nr 2, przyp. 3.

${ }_{5}$ Zob. nr 1, przyp. 5.

${ }^{6}$ Zob. $n r$ 4, przyp. 4.

7 Zob. nr 3, przyp. 7.

8 Zob. nr 3, przyp. 9.

${ }^{9}$ Zob. nr 2, przyp. 6.

${ }^{10}$ Wacław Sparer, brat w klasztorze św. Wojciecha w 1405 i 1410 r. (nr 6, 8). Od 1413 r. biskup lidoryceński, a od 1418 r. sufragan biskupa włoctawskiego; zob. P. Czaplewski, Tytularny episkopat w Polsce średniowiecznej, Poznań 1915, s. 116-118; por. K.R. Prokop, Biskupi pomocniczy w diecezjach polskich w dobie przedtrydenckiej (2. pot. XIII - 1. pot. XVI w.), Kraków 2002, s. 306-307.

${ }_{11}$ Marcin, spowiednik sióstr od św. Katarzyny w 1405 r. ( $\mathrm{nr}$ 6).

12 Jan Patcheyn (Patchein, Pathcheyn), spowiednik sióstr od św. Katarzyny w 1405 r. (nr 6). Spowiednik braci w 1410 r. (nr 8).

${ }^{13}$ Andrzej Swidnicz, przeor brzeski w 1414 r.; zob. K. Eisert, Das Dominikanerkloster in Brieg (1336-1545), „Archiv für Schlesische Kirchengeschichte” 18, 1960, s. 85. Świdnica, miasto na Dolnym Śląsku, lokowane w XIII w. Od końca XIII w. w mieście znajdowat się dominikański klasztor Krzyża Świętego.

14 Zob. nr 3, przyp. 10.

15 Tomaszko, brat w klasztorze św. Wojciecha w 1405 r. (nr 6).

16 Zob. $n r$ 4, przyp. 10.

17 Zob. nr 3, przyp. 11.

18 Katarzyna z Nysy, mniszka w klasztorze św. Katarzyny w 1391 r., jako przeorysza wspomniana również w 1399 r.; zob. H. Kulig, Die Standesverhältnisse des Breslauer Klarenstiftes im Mittelalter, Breslau 1939, s. 66, 71.

19 Katarzyna Voytchyn, mniszka w klasztorze św. Katarzyny w 1399 r.; zob. tamże, s. 72.

${ }^{20}$ Dorota Rutheni, mniszka w klasztorze św. Katarzyny 1356 r.; zob. tamże, s. 69. 
Bohemicalis monete pagamentique Polonicalis recepisse ad comparandum censum quatuor marcas, quod quidem censum comparavimus, tres marcarum in et super domo, sita prope aciem ex opposito cimiterii ecclesie sancti Adalberti, honesti viri Johannis Sponsbrucke civis Wratislaviensis ac super bonis eiusdem, quartam vero marcam super duobus mansis cum dimidio Gregorii et fratris sui rusticorum in villa dicta Stevy, Nympcensis ${ }^{21}$ districtus, iuxta tenorem littere domini hereditarii eiusdem ville desuper confecte, ratione cuius testamenti nos obligavimus et obligamus per presentes ad legendam unam missam perpetuam singulis diebus in altari Corporis Christi ecclesie sancte Katherine dictarum sororum. In quorum omnium fidem, robur et testimonium sigillum nostri conventus ac prioratus duximus presentibus appendendum. Datum Wratislavie, feria sexta infra octavam Epiphanie Domini, anno Domini millesimo $\mathrm{CCCCV}^{\circ}$. Promittimus insuper, quod si prefatus ${ }^{\mathrm{a}}$ census IIII ${ }^{\text {or }}$ marcarum in parte vel in toto solutus fuerit, loco illius pro eadem pecunia alium huic consimilem reempturum.

${ }^{b}$ Et ego frater Johannes Arnsberg ${ }^{22}$, prior provincialis provincie Polonie ordinis suprascripti, recognicioni, obligacioni, promissioni cum omnibus et singulis clausulis et punctis, prout premittitur, suprascriptis consensi et consencio eaque omnia et singula approbo et ratifico auctoritate[?] nostra gerenda et in robur firmius presentes mei provincialatus appendenti sigillo communivi ${ }^{-\mathrm{b}}$.

\footnotetext{
${ }^{a}$ Częściowo zatarte.

${ }^{b-b}$ Inną ręką.

${ }^{21}$ Ziemia niemczańska na południe od Wrocławia, nazwa pochodzi od Niemczy, w której znajdowat się zamek.

${ }^{22}$ Jan Arnsberg, przeor toruński w 1400 r., prowincjat w latach 1402-1410; R.-J. Loenertz, Une ancienne chronique, s. 38; W. Bucichowski, Lista lektorów dominikańskich, s. 125; R. Kubicki, Środowisko dominikanów kontraty pruskiej od XIII do połowy XVI wieku, Gdańsk 2007, s. 162, nr 194.
} 
Przeor Tadeusz i bracia z klasztoru św. Wojciecha we Wrocławiu oświadczaja, że w 1396 r. przyjęli 24 grzywny od sióstr z klasztoru św. Katarzyny, zobowiazujac się odprawiać msze święte za zmarle zakonnice, a obecnie otrzymali od Katarzyny Rychelin, siostry z tegoż klasztoru, kolejne 24 grzywny i zobowiazuja się odprawiać codziennie mszę święta przy ottarzu NMP w kościele św. Katarzyny w intencji Doroty, Małgorzaty i Katarzyny Rychelin. Dokument potwierdza prowincjat Jan Arnsberg

Or.: AP Wroctaw, Rep. 58, $n r$ 154. Pergamin $314 \times 161+25$ mm, dobrze zachowany, inicjat „N”. Zachowata się jedynie pieczęć prowincjała, przywieszona na pasku pergaminowym, a na zakładce nacięcia od pasków pozostatych dwóch pieczęci. Na odwrociu znajdują się streszczenia (XV-XVIII w.) oraz numery inwentarzowe i pieczęć archiwum z XIX w.

Noverint universi presentem paginam inspecturi, quod nos fratres conventus et monasterii sancti Adalberti in Wratislavia, ordinis Fratrum Predicatorum, videlictet Thadeus ${ }^{1}$ prior, | Petrus Wassirrabe ${ }^{2}$ sacre theologie professor, Johannes Glywicz ${ }^{3}$ heretice pravitatis inquisitor, Paulus Mundil ${ }^{4}$ lector, Augustinus ${ }^{5}$ lector, Petrus Gerstman ${ }^{6}$ lector domus, | Johannes de Rathibur ${ }^{7}$ supprior, Mathias de Brest ${ }^{8}$ cursor, Mathias Beruchz ${ }^{9}$, Wenceslaus Sparer ${ }^{10}$, Martinus ${ }^{11}$ et Johannes Patcheyn ${ }^{12}$ confessores sororum, Nicolaus Falcz ${ }^{13}$, | Thomasko ${ }^{14}$, Laurencius ${ }^{15}$, Michael de Nova Civitate ${ }^{16}$ et Laurencius Knote ${ }^{17}$ ceterique fratres prenominati conventus fatemur in his scriptis, quod dictus frater Mathias Beruchz, protunc prior existens, sub anno Domini $\mathrm{M}^{\circ} \mathrm{CCC}^{\circ} \mathrm{XCVI}^{\circ}$ de licencia reverendi patris fratris Andree Rutheni ${ }^{18}$, prioris provincialis provincie Polonie felicis recordacionis, ordinis eiusdem, recepit XXIIII ${ }^{\text {or }}$ marcas grossorum Bohemicalis monete Polonicalisque pagamenti pro tribus missis quibuslibet ebdomadis in sepultura sororum monasterii sancte Katherine, dicti ordinis, in Wratislavia celebrandis pro animabus, quarum corpora ibidem in Christo requiescunt quodque frater Thadeus prefatus, prior conventus et ordinis dictorum, similiter XXIIII ${ }^{\text {or }}$ marcas grossorum eiusdem monete ac pagamenti percepit a Katherina Rychelinne ${ }^{19}$, sorore prescripti monasterii sancte Katherine, de voluntate priorisse et omnium sororum eiusdem monasterii, pro quibus omnibus nos ad perpetuam missam singulis diebus per ebdomadam in altari Beate Virginis ecclesie sancte Katherine ibidem legendam, ob remedium salutare pie memorie Dorothee Rychelin et Margarethe Rychelin ${ }^{20}$ nec non prenominate Katherine Rychelinne, sororum sepedicti ordi-

1 Zob. nr 3, przyp. 2.

2 Zob. nr 3, przyp. 1.

3 Zob. nr 3, przyp. 3.

${ }_{4}^{4}$ Zob. nr 2, przyp. 3.

5 Zob. nr 1, przyp. 5.

${ }^{6}$ Zob. nr 4, przyp. 4.

Zob. nr 3, przyp. 9.

${ }^{8}$ Zob. nr 3, przyp. 7.

9 Zob. nr 2, przyp. 6.

${ }^{10}$ Zob. nr 5, przyp. 10.

11 Zob. nr 5, przyp. 11.

12 Zob. nr 5, przyp. 12.

13 Zob. nr 3, przyp. 10.

14 Zob. nr 5, przyp. 15.

15 Zob. nr 2, przyp. 7.

${ }_{16}$ Zob. nr 4, przyp. 10.

17 Zob. nr 3, przyp. 11.

18 Andrzej Rusiniec, przeor krakowski przed 1390 r., prowincjat w latach 1396-1401; zob. R.-J. Loenertz, Une ancienne chronique, s. 37-38.

19 Katarzyna Reichel, mniszka w klasztorze św. Katarzyny w 1397 r.; zob. H. Kulig, Die Standesverhältnisse, s. 71.

${ }^{20}$ Matgorzata Reichel, mniszka w klasztorze św. Katarzyny w 1401 r.; zob. tamże, s. 72. 
nis et monasterii ac pro quibus ipse intendebant seu ipsa Katherina intendit inviolabiliter observaturos. Neque tam iusta et pia predictarum sororum frustretur intencio, censum duarum marcarum pro pecunia ultimo per nos recepta promittimus, quam cito poterimus, emendum, qui si redemptus vel solutus fuerit, pecuniam eandem nullibi expendendam. Sed in loco alio securo pro eadem censum consimilem reemendum. In cuius obligacionis robur et testimonium presentem litteram sigillo nostrorum conventus ac prioratus officii fecimus communiri. Datum Wratislavie, feria secunda proxima post dominicam in Quadragesima, qua cantatur "Oculi", anno Domini millesimo CCCCV .

${ }^{a}$-Et ego frater Johannes Arnsberg ${ }^{21}$ prior provincialis provincie Polonie et ordinis suprascripti recognicioni, obligacioni, promissioni cum omnibus punctis ac clausulis, prout premittitur, suprascriptis consensi et consencio, eaque omnia approbo et ratifico et in robur firmius presentes mei provincialatus appendendo sigilli communivi ${ }^{-\mathrm{a}}$.

a-a Inną ręka.

${ }^{21}$ Zob. nr 5, przyp. 22. 
Przeor Tadeusz i bracia z klasztoru św. Wojciecha we Wrocławiu potwierdzaja, że Piotr Wasserrabe, za zgoda prowincjała Jana Arnsberga, ofiarowat konwentowi 30 grzywien groszy czeskich, w zamian za co konwent przyznat mu dożywotnio 3 grzywny czynszu rocznego z domu Jana Feystelinta, stojacego na placu św. Wojciecha

Or.: AP Wrockaw, Rep. 57, $\mathrm{nr} 56$ (108). Pergamin $410 \times 230+50 \mathrm{~mm}$, dobrze zachowany, uszkodzenia na zgięciach pergaminu, ozdobny inicjat „I” do ok. 1/3 wysokości tekstu. Na zaktadce nacięcia od pasków trzech pieczęci. Na odwrociu znajduja się streszczenia (XV-XVIII w.) oraz numery inwentarzowe i pieczęć archiwum z XIX w.

In nomine Domini, amen. Noverint universi, ad quorum noticiam presens venerit scriptum, quod nos fratres infrascripti: Tadeus ${ }^{1}$ prior, Johannes ${ }^{2}$ inquisitor heretice pravitatis, Augusti|nus ${ }^{3}$ lector, Petrus Gerstman $^{4}$ lector regens, Albertus ${ }^{5}$ lector, Ambrosius ${ }^{6}$ cursor, Michael de Nova Civitate $^{7}$ supprior, Mathias Berusz ${ }^{8}$, Salomon ${ }^{9}$ et Laurencius ${ }^{10}$ terminarius, Laurencius Knote ${ }^{11}$ sacrista, | Johannes Penestici, Vincencius, Bartholomeus ${ }^{12}$, Johannes Strelin ${ }^{13}$, Nicolaus Taczolt ${ }^{14}$ ceterique fratres conventus Wratislaviensis apud sanctum Adalbertum provincie Polonie, ordinis Predicatorum, recognos|cimus per presentes reverendum patrem fratrem Petrum Wasserrabe, sacre theologie magistrum ac olim priorem provincialem provincie dicte Polonie, nobis seu nostro conventu Wratislaviensi predicto optasse et dedisse triginta marcas Bohemicalis pagamenti Polonicalis numeri ex speciali affectu, quem ad nostrum gerit et gessit conventum, spem habens retribuendarum a fratribus orationum ac vicissitudinis aliquante temporalis pro sua necessitate corporali. Volentes igitur huiusmodi ipsius donacioni vicem rependere et intencioni eidem dicto reverendo patri fratri Petro Wasserrab ${ }^{15}$ tres marcas annui census annis singulis tollendas, quas noster conventus comparavit et emit in et super domo Johannis Feystelint, vicina domui aci[a]li a sinistra, exeundo [ad] conventum, in platea sancti Adalberti nunccupata libereque tulit ad usuma ${ }^{\text {a }}$ habuit et possedit, sine fraude et dolo, donavimus, dedimus unanimique nostrum omnium

${ }^{a}$ udum.

${ }^{1}$ Zob. nr 3, przyp. 2.

2 Zob. nr 3, przyp. 3.

${ }^{3}$ Zob. nr 1, przyp. 5.

${ }_{4}^{4}$ Zob. nr 4, przyp. 4.

5 Wojciech (Albert), może tożsamy z Albertem z Gdańska, od 1384 r. lektorem artium w Brześciu Kujawskim; zob. T. Gałuszka, Fragmenty czternastowiecznych akt, s. 119-120.

${ }^{6}$ Ambroży, lektor w 1410 (nr 8) i 1411 r.; Biblioteka Uniwersytecka we Wrocławiu, rkps IV F 57, karta ochronna. W 1413 r. skierowany przez kapitute generalna do Padwy z wykladami pro forma et gradu magisterii; zob. K. Kaczmarek, Szkoły i studia, s. 428-429, $\mathrm{nr} 12$

Zob. $n r$ 4, przyp. 10.

8 Zob. nr 2, przyp. 6.

${ }_{9}^{9}$ Salomon, brat w klasztorze św. Wojciecha w 1420 r.; AP Wrockaw, Rep. 57, nr 86 (138).

${ }_{10}$ Zob. nr 2, przyp. 7.

11 Zob. nr 3, przyp. 11.

12 Bartłomiej, może tożsamy z bratem o tym imieniu przeniesionym przez prowincjała z Cieszyna do Wrocławia w 1372 r. (Zbiór formut zakonu dominikańskiego prowincji polskiej z lat 1338-1411, wyd. J. Woroniecki, J. Fijałek, AKH, t. 12, 1919-1938, cz. 2, $n$ r 151) lub Barttomiejem Thuraw wystepujacym we Wrocławiu w 1415 r. (zob. nr 9).

13 Jan Strelin, prawd. ok. 1387 r. studiowat w Pradze, a nastepnie wstapit do zakonu we Wrocławiu; Biblioteka Uniwersytecka we Wroctawiu, rkps I Q 53, karta ochronna i k. 82; P. Kielar, Studia nad kultura szkolna i intelektualna dominikanów prowincji polskiej w średniowieczu, w: Studia nad historiq dominikanów w Polsce 1222-1972, t. 1, red. J. Kłoczowski, Warszawa 1975, s. 328. Strzelin, miasto na Dolnym Ślasku, lokowane w XIII w.

${ }_{14}$ Zob. nr 3, przyp. 12.

${ }_{15}$ Zob. nr 3, przyp. 1. 
consilio irrevocabiliter damus et assignamus singulis, ut premittitur, annis [...]ves ${ }^{\mathrm{b}}$ pro ipsius necessitate, quamdiu et ubicumque vixerit et in humanis moram traxerit tollendas in certis terminis c-prout

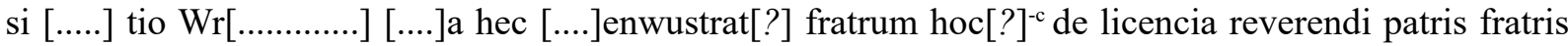
Johannis Arnsberg ${ }^{16}$, provincialis nostri, petita pariter et optenta ${ }^{\mathrm{d}}$. Postquam autem idem reverendus pater frater Petrus Wasserrabe debitum carnis solverit universe, predicte tres marce census ad nostrum revolvi debeant conventum, et quia predicti patris pecunia in utilitatem nostri conventus cessit specialiterque domus ex opposito walve nostre, per fratrem Mathiam Berusz secularibus personis vendita, ea ipsa pecunia est redempta, quo predictus census non est diminutus ymmo amplius augmentatus. Nos supranominati fratres seu totus noster conventus volentes ad voluntatem repeti patris fratris Wasserrabe, ipsius pie intencioni bona et spirituali vice respondemus, cum salutem animarum intenderit. Nos omnes et singulos atque successores nostros animo deliberato et consilio maturo omnium nostrum obligamus $^{\mathrm{e}}$ per presentesque obligatos protestamur ad legendas et observandas in perpetuum tres missas singulis septimanis, per fratrem ad hoc per tabularium annotatum, pro animabus fratrum et sororum et pro quibus intendit, hic et ubique quiescencium in Christo, committentes nostris et futurorum fratrum ${ }^{\mathrm{f}}$ omnium conscienciis execucionem huiusmodi efficacem. Si autem, velut ${ }^{\mathrm{g}}$ variabilis mundi instabilitas sepius demonstrat, contingeret predictum trium marcarum censum redimi sive quocumque modo alienari, aut ipsa talis modi donacio et assignacio nostris male informatis prelatis et presidentibus assumentibus ve[1] causam pro non causa displiceret, ne prefatus pater dampnum incurrat, ad possessionem domus eum debebimus seu noster conventus reponere et promittimus supranotate quousque de aliis tribus marcis annui census ei fuerit provisum vel pecuniam nobis traditam rehibeat capitalem integraliter et ex toto. In cuius rei testimonium sigillis reverendi videlicet patris nostri provincialis nec non nostrorum conventus et officii prioratus presentem paginam subappendendis fecimus roborari. Datum Wratislavie predicte, anno Domini $\mathrm{M}^{\circ} \mathrm{CCCC}^{\circ} \mathrm{VII}^{\circ}$, die tertia mensis februarii.

\footnotetext{
${ }^{b}$ Dziura $w$ pergaminie.

${ }^{c-c}$ Dziura na zgięciu pergaminu.

${ }^{d}$ Zatarte na zagięciu pergaminu.

e Wyraz częściowo uszkodzony, dziura w pergaminie.

${ }^{f}$ Częściowo zatarte.

${ }^{g}$ velud.

${ }^{16}$ Zob. nr 5, przyp. 22.
} 
Przeor Maciej Witchendorf i bracia z klasztoru św. Wojciecha we Wrocławiu potwierdzają, że Katarzyna Dumoslynne, siostra z klasztoru św. Katarzyny, ofiarowała im czynsze roczne: 2 grzywny z Kamieńca Wrocławskiego i 2 grzywny z Bukowic oraz 10 grzywien na zakup piatej grzywny czynszu. Zakonnicy zobowiązuja się odprawiać codziennie mszę święta przy ottarzu św. Anny w kościele św. Katarzyny. Dokument potwierdza prowincjat Jan Arnsberg

Or.: AP Wroctaw, Rep. 58, $\mathrm{nr}$ 172. Pergamin $272 \times 150+11 \mathrm{~mm}$, dobrze zachowany, ozdobny inicjal „W”. Na paskach pergaminowych pieczęcie konwentu i przeora, pośrodku na sznurku konopnym pieczęć prowincjata. Na odwrociu znajduja się streszczenia (XV-XVIII w.) oraz numery inwentarzowe i pieczęć archiwum z XIX w.

Wissen sollen alle, di desim brif sehen, horen oder lezen, das wir bruder des closters zu sante Albrecht in Bresslaw | der Prediger ordin, Mathias Wytchendorf ${ }^{1}$ prior, Petrus Wasserabe ${ }^{2}$ meyster der heylgen schrift, Johannes Gleywicz ${ }^{3}$ inquisitor, Augustinus ${ }^{4}$ lezemeister, Petrus Gerstman ${ }^{5}$ und Ambrosius $^{6}$ lezemeistern des hauses, Martinus Thawraw ${ }^{7}$, Jacobus $\mid$ Zeydel supprior, Nicolaus Bravensberg ${ }^{8}$ lezemeister und confessor, Michael Gilgenborg ${ }^{9}$ cursos, Johannes Pathcheyn ${ }^{10}$ confessor, Wenceslaus Sparer $^{11}$, Nicolaus Salomonis ${ }^{12}$ und Lorencz Knote ${ }^{13}$ scheffer und alle ander bruder des selben closters und ordins bekennen offenlich, daz wir enphangen haben von jungfre Katherein Dowmlozynne ${ }^{14}$ wein swester zu sente Katherin im closter zu Bresslaw vir marg zinses, tzwu zum Steyne ${ }^{15}$ und tzwu zu Vrawenwalde ${ }^{16}$, eyn itzliche marg gekauft umb tzen bereite marg groschen und auch dorober tzen marg groschen zu keufen di fumfte marg zins. Dorumb vorbinde wir uns vorgenanten bruder und unser nochkomelingen des selben closters und ordins bruder zu einer ewegen messen alle tage zu lezen of sente Annen altar under dem gewelbe in der kirchen czu sente Katherin und ap di zelben zinse worden apgelost, zo gelobe wir ander fumf marg zinses weder zu keufen umb fumftzik marg groschen und ap man umb di fumftzig marg nicht gekeufen mochte ander fumf marg zinsis, zo gelobe wir an arg umb di selben fumftzik marg zu keufen vir marg zins, und ap der zelbe czins an eime teile oder mittenader vorginge, dennoch solle wir di vorgeschreben misse ewiclich halden. Des zu orkunde und vestegunge

\footnotetext{
${ }^{1}$ Maciej Witchendorf, przeor świdnicki w 1391 r; zob. H. Schubert, Bilder aus der Geschichte der Stadt Schweidnitz, Schweidnitz 1911, s. 187. Witków (Wittgendrof), miejscowość na Dolnym Śląsku w pow. wałbrzyskim lub inna miejscowość o tej nazwie w pow. legnickim lub żagańskim.

2 Zob. nr 3, przyp. 1.

${ }^{3}$ Zob. nr 3, przyp. 3.

4 Zob. nr 1, przyp. 5.

${ }^{5}$ Zob. $n r$ 4, przyp. 4.

${ }^{6}$ Zob. $n$ r 7, przyp. 6.

Zob. $n r$ 1, przyp. 6.

${ }^{8}$ Braniewo (Braunsburg), miasto na Warmii w pow. braniewskim, lokowane $w$ XIII $w$.

${ }^{9}$ Michat Gilgenborg, w 1426 r. skierowany przez kapitute generalna do Krakowa $z$ wykładami pro forma et gradu magisterii; zob. W. Bucichowski, Lista lektorów dominikańskich, s. 163, nr 662; K. Kaczmarek, Szkoły i studia, s. 518, nr 340, M. Zdanek, Szkoty i studia dominikanów krakowskich w średniowieczu, Kraków 2005, s. 166. Dąbrówno (Gilgenburg), miasto na Mazurach w pow. ostródzkim, lokowane w XIV w.

10 Zob. nr 5, przyp. 12.

${ }_{11}$ Zob. $n r$ 5, przyp. 10.

12 Mikolaj Salomonis, furtian w 1415 r. (nr 9).

13 Zob. nr 3, przyp. 11.

${ }_{14}$ Katarzyna Daulmose, mniszka w klasztorze św. Katarzyny w 1360 i 1397 r.; zob. H. Kulig, Die Standesverhältnisse, s. 69, 71.

${ }^{15}$ Kamieniec Wrocławski, miejscowość na Dolnym Śląsku w pow. wrocławskim. Na przełomie XIV i XV w. mianem Steyn określano także sąsiedni Gajków.

${ }^{16}$ Bukowice (Frauwaldau), miejscowość na Dolnym Śląsku, w pow. milickim.
} 
habe wir an dezen briff lossen hengen unsers vaters, bruders Johannis Arnsberg ${ }^{17}$ provincialis in der provinzien zu Polen des vorgeschreben ordens ingesegel und des egenanten klosters und prioris amechtis ingesegel. Gegeben zu Bresslaw noch Cristus gebort vyrcze[h]en hundert jor und in dem czenden jore an sante Ambrosii tage des heiligen bischofis.

Et ego frater Johannes Arnsberg, prior provincialis provincie Polonie, omnia et singula suprascripta tenore presencium ratifico, approbo ac coroborando plenarie et confirmo, volens omnia presentis littere iuxta tenorem inviolabiliter observari. In quorum omnium confirmacionis testimonium sigillum mei provincialatus decrevi presentibus appendendum anno Domini et die mensis prenotatis.

${ }_{17}$ Zob. nr 5, przyp. 22. 
Przeor Tadeusz i bracia z klasztoru św. Wojciecha we Wrocławiu potwierdzaja, że Klara Zechsynne, siostra z klasztoru św. Katarzyny, przekazała konwentowi 52 grzywny groszy czeskich, przeznaczonych na zakup czynszu rocznego i zobowiazuja się odprawiać codziennie mszę święta przy oltarzu Matki Boskiej w kościele św. Katarzyny. Dokument potwierdza prowincjat Jan Biskupiec

Or.: AP Wroctaw, Rep. 58, nr 193 (194). Pergamin 292 x $258+46$ mm, dobrze zachowany, ozdobny inicjat „I”, pismo ozdobne, $w$ pierwszym i ostatnim wierszu dodatkowo ozdobione motywami roślinnymi. Na paskach pergaminowych pieczęcie prowincjała, konwentu i przeora (uszkodzona). Na odwrociu streszczenia (XV-XVIII w.) oraz numery inwentarzowe i pieczęć archiwum z XIX w.

Lit.: J. Heyne, Dokumentirte Geschichte, t. 2, s. 723; J. Fijałek, Dwaj dominikanie krakowscy Jan Biskupiec i Jan Falkenberg. W pięćsetna rocznice odwolania satyry antypolskiej Falkenberga w Rzymie w 1424 roku, w: Księga pamiątkowa ku czci Oswalda Balzera, t. 1, Lwów 1925, s. 289; tenże, Wstęp, w: Zbiór formut zakonu dominikańskiego prowincji polskiej z lat 1338-1411, wyd. J. Woroniecki, J. Fijatek, AKH, t. 12, 1919-1938, cz. 2, s. 225; J. Turek, Podziat polskiej prowincji dominikanów w czasach prowincjalatu Jana Biskupca w latach 1415-1417, Przegl. Hist., 106, 2015, nr 2, s. 311

Ad perpetuam rei memoriam. Nos infrascripti ${ }^{a}$, videlicet Tadeus ${ }^{1}$ prior et per Poloniam heretice pravitatis | inquisitor, Johannes Gleyvicz ${ }^{2}$ lector et eiusdem pravitatis per dyocesim Wratislaviensem inquisitor, Johannes Hollant ${ }^{3}$ subprior, Martinus Kolbil ${ }^{4}$ cursor, Andreas Tyncz ${ }^{5}$ sacrista, Nicolaus Salomonis ${ }^{6}$ portarius, Ge orgius Rosenthal ${ }^{7}$ procurator, Nicolaus Vomer ${ }^{8}$ et Andreas Kracwycz confessores sororum apud sanctam Katherinam, Bartholomeus Thuraw ${ }^{9}$, Nicolaus Vectoris, Petrus Bognaw ${ }^{10}$, Johannes Fflosser, Jacobus Fflosser, Petrus Reychil, Mathias Lyncz, Andreas Piscatoristerminarii, Martinus de Glogovia ${ }^{11}$, Nicolaus Peyzenkreczym, Albertus de Briesa ${ }^{12}$, Johannes Reychenbach ${ }^{13}$, Jacobus Newirt, Georgius Newiar, Nicolaus Carnificis ${ }^{14}$, Michael Falsatoris ${ }^{15}$, Nicolaus Rex aliique omnes et singuli fratres monasterii sancti Adalberti Wratislavie, ordinis Predicatorum, omnibus, ad quos presentes littere pervenerint, cupimus fore notum, quod ab honesta et devota puella Clara Zechsynne, sorore professa monasterii sancte Katherine Wratislavie, sub cura et obedientia fratrum predicatorum constituti,

${ }^{a}$ inffrascripti.

1 Zob. nr 3, przyp. 2.

2 Zob. nr 3, przyp. 3.

3 Zob. nr 4, przyp. 13.

${ }^{4}$ Marcin Kolbil, lektor w 1445 r.; zob. G.M. Löhr, Breslauer Dominikaner des 15. Jahrhunderts auf auswärtigen Hochschulen, „Archivum Fratrum Praedicatorum”, 13, 1943, s. 171, nr 15; W. Bucichowski, Lista lektorów dominikańskich, s. 151, nr 581; K. Kaczmarek, Szkoty i studia, s. 509, $n r 307$.

5 Tyniec Mały, miejscowość na Dolnym Ślasku w pow. wrocławskim.

${ }^{6}$ Zob. $n r$ 8, przyp. 12.

Różanka (Rosenthal), miejscowość na Dolnym Śląsu w pow. kłodzkim lub dzisiejsza dzielnica Wrocławia.

${ }^{8}$ Mikołaj Vomer, subprzeor toruński w 1397 r. Brat w tym klasztorze w 1400 r. W 1409 r. lektor w Elblagu; zob. R. Kubicki, Środowisko dominikanów, s. 181, nr 514 i 515.

9 Zob. nr 7, przyp. 12.

${ }^{10}$ Bojanów, miejscowość na Górnym Ślasku w pow. raciborskim.

${ }^{11}$ Marcin z Głogowa, zakrystian w klasztorze poznańskim w 1413 r.; K. Kaczmarek, Konwent dominikanów poznańskich, s. 48. Głogów, miasto na Dolnym Śląsku, lokowane w XIII w., stolica księstwa głogowskiego. Od połowy XIII w. w mieście znajdowat się dominikański klasztor św. Piotra.

12 Brzezie, miejscowość na Dolnym Ślasku w pow. trzebnickim.

${ }_{13}$ Dzierżoniów (Reichenbach), miasto na Dolnym Ślasku, lokowane w XIII w.

${ }^{14}$ Mikołaj Carnificis (Carnifex), brat w klasztorze elblaskim w 1409 r. Przeor elbląski w 1429 r.; zob. R. Kubicki, Środowisko dominikanów, s. 178, nr 466.

${ }^{15}$ Michat Falsatoris, subprzeor w 1424 r. (nr 10). 
cum effectu percepimus quinquaginta duas marcas latorum Bohemicalium grossorum Polonici numeri, de quibusquidem pecuniis tenemur comparare quatuor marcas census annui per priorem, qui pro tempore fuerit, tollendas ac inconsequens fratrum usus exponendas perpetuo, racione cuius nos nostrosque posteros obligavimus ad dicendam diebus singulis temporibus perpetuis unam missam ad altare beate Dei Genitricis semperque Virginis Marie, quod ipsa soror Clara in ecclesia dicti monasterii sancte Katherine rexit et consumavit pro salvatione ipsius progenitorumque suorum et pro quibus ipsa intendit inpretermisse. Et ut hoc per nos vel per eos, qui post nos fuerint, nullo modo negligatur, presentibus nos et eos, qui nobis succedunt, submittimus, quatenus si prelibate pecunie in alios usus committentur, quam in census, itaque non haberemus redditum, ut premissum est, quatuor marcarum, nichilominus fideliter missam in perpetuum continuabimus superscriptam, que si inde neglecta fuerit, eo ipso fratres germani et qui com[m]issarii dicte sororis Clare fuerint in parte habeant omnem potestatem coram nostri ordinis superiore de hoc agendi et de prenotatis quinquaginta duabus marcis per censum annuum quatuor marcarum ius sibi repetendi, donec instauretur negligencia commissa. In quorum testimonium sigilla videlicet nostri conventus et officii prioratus presentibus sunt subappensa. Verum tamen, ut hec ipsa robor tenoris firmitatis obtineant, consensu reverendi patris nostri, fratris Johannis Episcopi ${ }^{16}$, sacre theologie professoris et provincie nostre Polonie prioris provincialis, ad omnia supra gesta obtento, hanc litteram ipsius sigillo supra appenso inpetravimus communiri. Datum Wratislavie, in vigilia Epiphanie, anno Domini millesimo quadringentesimo quintodecimo.

${ }^{16}$ Jan Biskupiec, przeor krakowski w latach 1405-1411, prowincjat w latach 1411-1417, biskup chetmski w latach 1417-1452; W. Bucichowski, Lista lektorów dominikańskich, s. 128; K. Kaczmarek, Szkoły i studia, s. 476-477; R.-J. Loenertz, Une ancienne chronique, s. 37-38; T. Kaeppeli, E. Panella, Scriptores Ordinis Praedicatorum medii aevii, t. 4, Roma 1993, s. 145-146; J. Turek, Jan Biskupiec, prowincjat polskich dominikanów w latach 1411-1417, w: Ecclesia, regnum, fontes. Studia z dziejów średniowiecza, Warszawa 2014, s. 87-95. 
Dominik Beler, wikariusz prowincjała dla kontraty ślaskiej i przeor oraz bracia z klasztoru św. Wojciecha we Wrocławiu oświadczaja, że Agnieszka i jej córka Zofia za 48 grzywien wykupity czynsz roczny (4 grzywny) z domu Jana Rossiego, zapisany niegdyś klasztorowi testamentem Katarzyny Jokoschynne

Or.: AP Wroctaw, Rep. 57, nr 91 (143). Pergamin $314 x 166+18$ mm, dobrze zachowany. Na zaktadce nacięcia od pasków dwóch pieczęci. Na odwrociu streszczenia (XV-XVIII w.) oraz numery inwentarzowe i pieczęć archiwum z XIX w.

Nos fratres Dominicus Beler prior necnon vicarius contrate Slesie, Petrus Weychman ${ }^{1}$ sacre theologie doctor, Augustinus ${ }^{2}$ lector, Nicolaus Tilgener ${ }^{3}$ lector, | Michael Falsatoris ${ }^{4}$ supprior totusque conventus sancti Adalberti in Wratislavia, ordinis Predicatorum, tenore presencium recognoscimus universis et singulis, ad quos | presens scriptum pervenerit, presentes et futuros, quod honesta domina Katherina relicta condam Pauli Jokosch civis Wratislaviensis, dum in humanis ageret, | nobis suum laudabile et perpetuum testamentum condidit ${ }^{\mathrm{a}}$, videlicet quatuor marcas annui census super reempcione quamlibet marcam pro XII marcas grossorum computando, et assignavit super domo magna Johannis Rossi, civis Wratislaviensis, prope domum domini Johannis Trachenberg in platea sancti Adalberti et legavit pro anniversariis et vigiliis et missis legendis, prout in littera venerabilis patris magistri Petri Wassirrabe ${ }^{5}$ magistri sacre theologie et vicarii Slesie et prioris et conventus sigillum extitit roboratum et communitum, et super huiusmodi testamento exequendo suos legittimos et spirituales elegit executores, discretos et providos viros et scientificum magistrum Johannem Goldberg, magistrum arcium et doctorem in medicinis, Nicolaum Hartlip et iuratos pellificum, cives Wratislavienses. Et post mortem predicte domine Katherine Jokoschynne domus supranominata data est honeste domine Agnethe condam et advocate in Novo Foro ${ }^{6}$ et eius filie Sophie per supranominatos executores, predicta summa pecunie tradita et in iudicio coram schabinis in Wratislavia resignata. Et quia predicta domina Agnes cum Sophia filia sua domum eorum ab huiusmodi quatuor marcarum censu annui liberare volentes, priori et conventui sancti Adalberti in Wratislavia quadraginta octo marcas grossorum cum persessis censibus persolverunt in parata et numerata pecunia et in toto satisfecerunt, nos igitur predicti ${ }^{\mathrm{b}}$ prior et conventus sancti Adalberti in Wratislavia tenore presencium recognoscimus nobis et monasterio nostro esse in toto summam superdictam quadraginta octo marcarum grossorum persolutam et cum persessis a nobis perceptam, quare per presentes quietamus dominam Agnetam et Sophiam eius filiam et ipsorum heredes necnon super dicte domine Katherine Jokoschynne executores magistrum Johannem Goldberg, Nicolaum Hartlip, Balthezarem Beer et Nicolaum Sweydnicz iuratos pellificum, cives Wratislavienses et quietamus de supradicta summa pecunie quadraginta octo marcarum grossorum cum persessis per nos receptis. Eciam quietamus ipsos et ipsorum heredes et legitimos successores de amplius non petendo

\footnotetext{
${ }^{a}$ conddidit, pierwsza litera $\mathrm{d}$ została jednak przekreślona.

${ }^{b} \mathrm{~W}$ dokumencie błędnie predictos.

${ }^{1}$ Piotr Wichman, przeor toruński w 1408 r. W 1413 r. skierowany przez kapitule generalna do Kolonii z wyktadami pro forma et gradu magisterii. W latach 1427-1429 profesor $w$ Krakowie. W kolejnych latach przebywat $w$ Toruniu; zob. P. Kielar, Studia nad kultura, s. 373-392; A. Latkowski, Magister Piotr Wichman OP, „Przeglad Tomistyczny”, 2, 1986, s. 231-235; W. Bucichowski, Lista lektorów dominikańskich, s. 192, nr 890; K. Kaczmarek, Szkoły i studia, s. 544, nr 457; R. Kubicki, Środowisko dominikanów, s. 185-186, nr 579.

2 Zob. nr 1, przyp. 5.

${ }^{3}$ Mikołaj Tilgener, lektor; zob. W. Bucichowski, Lista lektorów dominikańskich, s. 178, nr 784; K. Kaczmarek, Szkoły i studia, s. 536, nr 415.

${ }_{4}$ Zob. nr 9, przyp. 15

${ }_{5}$ Zob. nr 3, przyp. 1.

${ }^{6}$ Nowy Targ, plac położony niedaleko klasztoru św. Wojciecha.
} 
nec per nos et successores nostros nec in iudicio spirituali nec seculari. Insuper, si alique littere vel instrumenta inventa fuerint, huiusmodi facta -instrumenta- testamenta et censum concernencia superdicta, nullius roboris debent esse et momenti. Acta sunt hec anno Domini $\mathrm{M}^{\circ} \mathrm{CCCC}$ XXIIII, die XXIX decembris, in domo Bernhardi Nobil ${ }^{7}$, presentibus discretis viris et dominis: domino Caspero altarista in Novo Foro, domino Johanne Trachenberg altarista sancti Petri in supremo Wratislavia, scientifico viro magistro Petro Leysnicz advocato consistorii Wratislaviensis et Johanne eius notario publico necnon Heynerano Snorbeyn, Johanne Honoman, Frischcone Dominici, Bernhardo Nobil. In cuius rei testimonium sigilla prioris et conventus sunt appensa.

\footnotetext{
${ }^{7}$ Bernhard Nobil z Dobroszowa, mieszczanin wrocławski, w 1408 r. spisat swój testament, $w$ którym poczynit legaty dla dominikanów; AP Wroctaw, Rep. 57 nr 58 (110).
} 


\title{
Nos fratres conventus sancti Adalberti. \\ The documents issued by the Wroclaw Convent of Dominicans in 1390-1424
}

\begin{abstract}
Summary: There are ten documents from 1390-1424 preserved in the State Archives in Wrockaw, issued by the Dominican convent of St. Adalbert in Wrocław; their intitulations name from five to twenty six friars. All these documents are kept in the State Archives in Wrocław. Compared to the entire Polish Dominican province, this is a unique group, because there is no other convent with similar documents issued during such a short period of time. These source texts have not yet been more thoroughly analysed and used by historians. An analysis of their content shows that they were issued by the prior, friars holding offices at the convent (lectors, inquisitors), and a group of the oldest and most experienced members of the congregation. The documents were sealed at the conventual chapter, and only the stamp of the convent was necessary to their authentication. These documents provide a good deal of new information on the composition of the Wrockaw Dominican convent and the careers of some of the friars. All the documents are published in the annex.
\end{abstract}

Nota o autorze: Jakub Turek, absolwent Instytutu Historycznego Uniwersytetu Warszawskiego (praca magisterska napisana pod kierunkiem prof. dr hab. Marii Koczerskiej na temat kontaktów dominikanów z klerem diecezjalnym w Polsce w XIII-XV w.) i Podyplomowych Studiów Varsavianistycznych tamże (2015-2016). Publikował w „Przeglądzie Tomistycznym” i „Przeglądzie Historycznym”. Zainteresowania badawcze: historia Kościoła, dzieje polskiej prowincji dominikanów w średniowieczu, biografie wybitnych przedstawicieli zakonu, rola intelektualistów w otoczeniu Władysława Jagiełły.

Author: Jakub Turek, graduate of the Institute of History of the University of Warsaw (MA thesis written under Prof. dr hab. Maria Koczerska on the contacts of Dominicans with the diocesan clergy in Poland in the $13^{\text {th }}-15^{\text {th }} \mathrm{cc}$.) and of the Postgraduate Warsaw Studies (2015-2016). The author of texts published in Przeglad Tomistyczny and Przeglad Historyczny. His research interests include: history of Church, history of the Polish Dominican province in the Middle Ages, biographies of outstanding members of the Dominican Order, role of intellectuals in the milieu of King Władysław Jagiello.

e-mail: jakub.turek@gazeta.pl

\section{Bibliografia}

Kaczmarek K., Konwent dominikanów wrocławskich w późnym średniowieczu, Wrocław 2008

Kaczmarek K., Szkoty i studia polskich dominikanów w okresie średniowiecza, Poznań 2005

Kłoczowski J., Dominikanie polscy na Śląsu w XIII-XIV wieku, Lublin 1956

Kubicki R., Środowisko dominikanów kontraty pruskiej od XIII do połowy XVI wieku, Gdańsk 2007

Turek J., Sigillum provincialatus cum Beata Maria Virgine. Studium pieczęci polskich prowincjatów dominikańskich z XIV i XV wieku, St. Źródł., 54, 2016, s. 59-84 